\title{
Reforma política no Brasil: indagações sobre o impacto no sistema partidário e na representação
}

Resumo: Os efeitos produzidos pelo método de converter votos em cadeiras têm estado no centro do debate brasileiro desde a Constituição de 1988 e a reforma política nunca deixou a agenda do debate político, dentro e fora da academia. Os argumentos, no geral, dizem respeito ao fortalecimento dos partidos e ao aumento da accountability eleitoral. Este artigo se propõe a analisar os efeitos de mudanças dos distritos eleitorais. Essas questões estão inscritas em uma discussão mais ampla sobre os impactos do sistema eleitoral no sistema político, bem como sobre o equilíbrio delicado entre governabilidade e representação. Consequentemente, estão diretamente relacionadas à qualidade do sistema democrático.

Palavras-chave: reforma política; partidos políticos; sistema eleitoral; distrito uninominal; lista fechada

\begin{abstract}
The effects produced by the method to convert votes into legislative seats have been at the center of the debate in Brazil since the 1988 Constitution, and since then political reform has never left the agenda of the political debate, both inside and outside of the university. The arguments are, in general, the strengthening of parties and the increase of electoral accountability. This article proposes to analyze the effects of changing the electoral districts. These issues are inscribed in a larger discussion about the impacts of the electoral system on the political system, as well as about the delicate balance between governability and representation. Consequently, they are directly related to the quality of the democratic system.
\end{abstract}

Keywords: political reform; political parties; electoral systems; uninominal voting; closed list 


\section{Introdução}

Em cinco de outubro de 1988 era promulgada, em Brasília, a nova Constituição do Brasil. Considerada por muitos como o marco final de uma longa transição democrática, a nova Carta constitucional passou, rapidamente, a ser alvo de análises de acadêmicos e especialistas a respeito do funcionamento das instituições políticas erigidas pela Assembleia Nacional Constituinte.

Esses autores (LAMOUNIER, 1994; MAINWARING, 1991; 1999) destacavam que a combinação entre o presidencialismo (de caráter plebiscitário) e a representação proporcional (RP) de lista aberta levaria o sistema político brasileiro ao colapso. Entre as possíveis soluções apresentadas para evitar esse resultado estavam a mudança do sistema de governo e do método de seleção dos deputados federais para um que proporcionasse aos partidos maior controle sobre seus membros, tanto na arena eleitoral quanto na arena legislativa. Quanto à primeira proposta, as pretensões se esgotaram após o plebiscito de 1993, quando, com 69,2\% dos votos válidos, a opção pelo sistema presidencialista saiu vencedora do plebiscito de $1993^{1}$

Todavia, se a opção de mudança do sistema de governo deixou de ser pauta entre os políticos e acadêmicos brasileiros, o mesmo não ocorreu com o sistema eleitoral. As críticas à RP e às demais características das eleições legislativas se tornaram mais ríspidas, e a reforma das regras eleitorais permanece central na agenda da reforma política debatida tanto no Legislativo como pela opinião pública em geral. Os escândalos de corrupção somados a outras "disfunções" do poder público alimentam um consenso de que os métodos de seleção de representantes precisam ser alterados, no anseio de que se altere, em última instância, a qualidade da representação.

É possível apontar dois objetivos comuns desses anseios de mudança: tornar o sistema partidário menos aberto à entrada de pequenos partidos e fortalecer os partidos políticos. Quanto às propostas feitas visando a tais efeitos, podemos listar a troca da lista aberta para a fechada, o fim das coligações, a criação de um sistema majoritário de distrito uninominal ou um sistema proporcional misto como o utilizado na Alemanha.

Não obstante o número de propostas de alteração do sistema eleitoral, nenhuma dessas sugestões saiu do papel. Os possíveis efeitos dessas alterações são deduzidos, de maneira geral, por inferência teórica ou pelo conhecimento que se tem da experiência de outros países. Neste artigo buscou-se ir além na indagação sobre os impactos que uma dessas transformações traria ao jogo político brasileiro. Nominalmente, simulou-se o resultado das eleições nos estados de São Paulo e Pernambuco, caso fossem criados distritos menores com magnitude variando de três a oito. Nossos resultados apontam que, em ambos os casos, os maiores partidos seriam beneficiados e o número de partidos efetivos apresentaria uma redução em mais da metade do valor verificado hoje nesses estados.

Além desta Introdução, este artigo está organizado em três seções. Na primeira seção apresentamos uma síntese das críticas às regras eleitorais brasileiras no pós-Constituinte que embasam os argumentos reformistas, focando em alguns aspectos centrais: a RP, a magnitude dos distritos, a lista

\footnotetext{
1 Após o plebiscito sobre a forma e o sistema de governo de 1993, apenas duas propostas de reforma do sistema de governo foram protocoladas: a PEC 20/1995 de Eduardo Jorge (PT.SP) e a PEC 282/2004 de Roberto Jefferson (PTB-RJ).
} 
SILVA, P. et al. Reforma política no Brasil: indagações sobre o impacto no sistema...

aberta e as coligações. Depois apresentamos a metodologia e os resultados dos exercícios. Por fim, realizamos algumas considerações sobre os resultados e sobre as propostas de reforma em geral.

\section{As críticas ao sistema eleitoral: uma breve revisão da literatura}

Grosso modo, o debate pioneiro que tratou da consolidação de nossas instituições desde a última redemocratização trouxe diagnósticos pessimistas sobre o funcionamento do sistema político brasileiro. As razões apontadas para isso são diversas, sobrepondo-se questões históricas, estruturais, culturais e, sobretudo, institucionais. Quanto a essa última espécie de argumentos, boa parte de nossas mazelas seria atribuída ao arranjo eleitoral. As regras empregadas para traduzir votos em cadeiras no Congresso são alvo de constantes críticas pela permissividade e pelo suposto incentivo ao individualismo dos políticos em detrimento dos partidos. Consequentemente, a reforma eleitoral vem sendo pautada desde então.

O aspecto mais geral das eleições para o Legislativo, o método proporcional, é problematizado por conta de seus impactos serem considerados especialmente nocivos no caso brasileiro. É sabido que as duas "grandes famílias" do sistema eleitoral - majoritário e proporcional - atendem a princípios distintos e produzem efeitos específicos sobre o sistema político quanto à governabilidade e à representatividade. Sobre o sistema partidário, esses efeitos são amplamente difundidos pela literatura desde o seminal estudo de Duverger (1987), dispensando maior detalhamento aqui. Quanto aos demais, resumiremos o debate que perpassa a literatura de ciência política.

O principal ponto dos defensores do sistema majoritário é que a RP fraciona o poder em muitas unidades diferentes, posto que um número grande de partidos conquista representação no parlamento, tendo como contrapartida uma maior dificuldade na produção de maiorias estáveis para governar. Haveria então necessidade constante de negociação do Executivo com os demais partidos, o que poderia levar o sistema político a crises de paralisia (LAMOUNIER, 1994). Outra crítica pontua que sistemas proporcionais dificultariam a accountability do sistema político (ARATO, 2002; SHUGART; CAREY, 1992; POWELL JR.; WHITTEN, 1993). O motivo seria que a necessidade do governo de realizar coalizões faria da atribuição de responsabilidades por parte do eleitor uma tarefa complicada. Não sendo clara a associação das ações do poder público com os seus responsáveis, a faceta retrospectiva do voto seria drasticamente dificultada.

Por sua vez, o principal argumento dos que defendem a RP é que a representação, antes de ser uma questão de governabilidade, seria uma questão de justiça (URBINATI, 2006; SANTOS, 1987; AMY, 2002). O sistema de RP seria o único capaz de dar voz a grupos minoritários da população, por não adotar um critério puramente territorial para definir o distrito eleitoral, possibilitando assim a representação de grupos espacialmente dispersos. Um ponto central é que a representação não é vista por esses autores como uma concessão de benefício das maiorias às minorias, mas como uma condição que, se não cumprida, torna o sistema político injusto. Nesse sentido, alguns deles apontam que determinados sistemas eleitorais são mais adequados que outros, tendo em vista o contexto político institucional. Elster (2008), por exemplo, afirma que a RP é desejável como mecanismo de seleção para 
membros de Assembleias Constituintes devido ao fato de atuar como um espelho da diversidade social, possibilitando a formação de crenças racionais por meio da maior quantidade de informação trazida pela heterogeneidade dos constituintes. Por sua vez, Amy (2002) sustenta, contra a noção de instabilidade da $\mathrm{RP}$, que sistemas majoritários podem levar a mudanças radicais da política, a depender de quem vence as eleições. Outro argumento levantado pelo autor é que a RP "politiza" a população ao adicionar substância às campanhas políticas, ao introduzir pontos de vista diversos na arena política visando à representação no parlamento.

De maneira abrangente, portanto, é possível assinalar o sistema majoritário como o método que mais facilita a governabilidade, enquanto a RP é identificada como modo de garantir maior representatividade. Naturalmente, dado o temor da literatura desenvolvida nos anos 1990 de que a recém-instaurada ordem democrática fosse mais uma vez rompida no Brasil, a preocupação com a governabilidade assumiu premência. A RP passou então a ser acusada de contribuir com a fragmentação partidária brasileira, gerando, de um lado, altos custos para a produção de governo, de outro, comprometendo a inteligibilidade do sistema partidário e dificultando o controle por parte do eleitorado sobre os políticos (LAMOUNIER, 1994; AMES, 1995; MAINWARING, 1991; 1999).

Quanto à questão da governabilidade e da estabilidade democrática, no cerne das referidas análises, houve significativo avanço com o trabalho de Figueiredo e Limongi (1999). Ao examinarem a estrutura do processo decisório no Congresso, os autores confrontaram as afirmações tradicionais sobre o conflito entre os poderes, a fragmentação excessiva e a indisciplina dos parlamentares, desconstruindo a premissa de que a arena legislativa seria reflexo direto da arena eleitoral. Com esse deslocamento analítico constatam justamente o contrário dos diagnósticos recorrentes: são altos os índices de disciplina e o padrão de organização dos trabalhos legislativos é fortemente centralizado em torno dos partidos.

Todavia, outros elementos devem ser acrescentados ao debate para compor a crítica mais geral que é feita às eleições legislativas. As consequências associadas ao modelo de lista aberta, por exemplo, aprofundam a crítica perene quanto à fragilidade dos partidos. Kinzo (2004) sustenta que, a despeito da estabilidade do funcionamento do sistema democrático brasileiro, a fragmentação propiciada pelo método proporcional mantém-se como problema na medida em que afeta a inteligibilidade do processo eleitoral pelo excesso de candidaturas. Ademais, a influência dos eleitores na seleção de candidatos se daria em detrimento do controle das lideranças partidárias sobre o processo de indicação. A lista aberta incentivaria, portanto, a formação de lideranças personalistas e a criação de lealdades extrapartidárias dos políticos com suas clientelas, de modo que as disputas para o Legislativo seriam antes entre candidatos individuais do que entre siglas, não contribuindo assim para a criação de identidades políticas sólidas. Mais do que isso, a lista aberta incentivaria a competição entre candidatos de um mesmo partido. Consequência lógica desse raciocínio seria o esvaziamento do papel dos partidos enquanto agentes relevantes na estruturação da competição eleitoral para o Legislativo.

De outro lado, trabalhos vêm apontando para a limitação da discussão a respeito da lista aberta. Nicolau (2006), por exemplo, crítico ao corte dedutivo que predomina nesses estudos, aponta que uma série de outros elementos poderia incidir na configuração dos partidos, incluindo a escolha de 
SILVA, P. et al. Reforma política no Brasil: indagações sobre o impacto no sistema...

determinadas regras internas à sua organização, que deve produzir variações importantes na estrutura partidária, matizando os efeitos do sistema eleitoral. Braga (2008), por sua vez, propõe que a lista seja vista como produto da atuação deliberada do partido, que construiria estratégias e alteraria seu comportamento de uma eleição para outra, de acordo com as variações da conjuntura eleitoral. Ao analisar a composição das listas partidárias em São Paulo, a autora argumenta que os partidos, ao controlarem recursos vitais do fundo partidário e do tempo no horário gratuito no rádio e na TV, acabam praticando uma ordenação informal da lista. Esses mecanismos organizativos funcionariam inclusive como controle da competição intrapartidária, revelando o papel fundamental desempenhado pelos partidos enquanto operadores da representação política. Conforme aponta Santos (1999), já que são pouquíssimos os candidatos a se eleger contando apenas com seus votos, não há de se descartar os incentivos no sentido de um comportamento coletivo, que reduza as incertezas eleitorais dos candidatos em um sistema tão competitivo quanto o brasileiro.

A crítica às coligações, por sua vez, ocorre no mesmo sentido da lista aberta: não seriam os partidos as unidades diferenciadoras na competição eleitoral, mas uma miríade de candidatos dentro de coligações compostas por diversos partidos indistintos ideologicamente. Para Kinzo (2004), a prática das coligações seria uma necessidade em virtude da fragmentação do sistema partidário e, ao mesmo tempo, a causa da entrada de pequenos partidos. A contrapartida do recurso estratégico às coligações por parte dos partidos seria a falta de nitidez do sistema partidário para o eleitorado, que não raro perderia a clareza de qual sigla seu voto beneficia. Resultaria daí outra consequência negativa das coligações: a transferência de votos dentro da coligação acarretaria a distorção entre o número de votos e o número de cadeiras, notadamente para os pequenos partidos, que obteriam espaço não correspondente ao seu lastro eleitoral (FLEISCHER, 1997). O conjunto desses fatores comprometeria diretamente a accountability vertical efetiva, aumentando a disparidade entre o sistema partidário eleitoral e o sistema partidário nas arenas decisórias.

Também quanto à capacidade do sistema de propiciar um vínculo de representação entre políticos e eleitores, é recorrente o debate sobre a magnitude dos distritos eleitorais brasileiros - mais ainda que o debate sobre a incorporação de elementos majoritários nas eleições legislativas, segundo Cintra (2005). O argumento mais geral é que a grande extensão das circunscrições eleitorais tornaria mais difícil a prestação de contas. Na ausência de bases eleitorais definidas, os deputados desfrutariam de grande autonomia em sua atividade parlamentar. Cheibub (2007) aponta ainda para outro aspecto do tamanho dos distritos: o alto nível de competitividade das eleições legislativas. Na contramão do argumento corrente sobre o voto pessoal, o autor afirma que os parlamentares não teriam garantias suficientes de que seriam premiados pelo bom mandato em uma próxima eleição, em razão da excessiva competitividade e dos altos custos de campanha envolvidos nessas disputas - o que pressionaria os candidatos na angariação de financiamento privado. Nesse mesmo sentido, Cintra argumenta que as vantagens da lista aberta quanto à aproximação direta entre político e eleitores com accountability não se manifestariam, dada a magnitude dos distritos eleitorais brasileiros. 


\section{Metodologia e resultados}

Conforme apresentado na Introdução, foi realizado um exercício de simulação de reforma eleitoral com o objetivo de refletir sobre o impacto do redesenho dos distritos eleitorais em duas unidades da federação: São Paulo, o maior colégio eleitoral brasileiro, e Pernambuco, o segundo maior do Nordeste, utilizando distritos eleitorais de magnitude de três a oito.

Optamos por esses valores baseados no argumento de Cheibub (2007) e Carey e Hix (2011). Cheibub argumenta que o sistema eleitoral brasileiro, RP com lista aberta, proporciona ao eleitor a opção de votar tanto no candidato e no partido como apenas no partido. Por conta da liberdade que isso confere ao eleitor, afirma que a configuração mais geral do sistema eleitoral deve ser mantida. Aponta, contudo, que nem por isso o sistema não poderia sofrer alterações incrementais, e sugere então uma mudança: a diminuição da magnitude dos distritos brasileiros para um número que variasse de três a seis cadeiras. Os motivos para a mudança seriam: diminuir o custo das campanhas, estimular os políticos a criar laços com seus eleitores e aumentar o grau de institucionalização do Congresso (CHEIBUB, 2007).

Por sua vez, Carey e Hix (2011) realizam um estudo comparado visando determinar qual seria a magnitude ideal para maximizar tanto a representação como a accountability de um sistema político, chegando ao valor mínimo de três e ao máximo de oito cadeiras. Utilizando dados para 81 países no período de 1946 a 2006, os autores apontam que a partir de oito cadeiras o acréscimo de representação, entendido como o aumento de partidos representados no parlamento, não é suficiente para justificar um incremento na magnitude do distrito. Se, por um lado, a magnitude entre três e oito cadeiras maximizaria a representatividade, por outro, também maximizaria a accountability. Carey e Hix, apoiados em estudos do campo da psicologia, sustentam que pessoas conseguem escolher estrategicamente com, no máximo, sete opções. Em cenários com um número de opções superior a sete, pessoas tenderiam a agir "honestamente" e a escolher de modo não estratégico, pois não saberiam calcular as chances de cada uma das possibilidades sair vencedora. De um lado, em sistemas em que o número de candidatos viáveis é maior do que sete a accountability seria prejudicada. De outro, em distritos com magnitude baixa, os eleitores tenderiam a agir de modo semelhante a como agiriam em distritos uninominais. Portanto, nossa opção por uma magnitude de três a oito foi amparada tanto na sugestão de Cheibub, como nos resultados de Carey e Hix.

Não obstante, antes de apresentarmos o método empregado, cabe um comentário sobre o estudo de Amorim Neto, Cortez e Pessoa (2011), que objetivou o redesenho dos distritos eleitorais de 12 estados brasileiros. Para a definição dos distritos, os autores utilizaram o software Skater (Spatial 'K'luster Analisys Through Edge Removal), que "define áreas homogêneas e contíguas a partir do agrupamento de áreas menores, segundo variáveis de homogeneidade" (AMORIM NeTO; CORTEZ; PESSOA, 2011, p. 56). As variáveis de homogeneidade utilizadas foram o Índice de Desenvolvimento Humano Educacional (IDH-E) e o IDH geral calculados com base no Censo de 2000. Após o uso do software, o número de distritos gerados para cada um dos estados variou de oito (São Paulo) a dois (Santa Catarina, Ceará, Maranhão e Goiás). Os autores destacam que "o Skater não busca maximizar o número de áreas 
SILVA, P. et al. Reforma política no Brasil: indagações sobre o impacto no sistema...

criadas, mas, sim, homogeneizá-las de acordo com as variáveis de controle" (AMORIM NETO; CORTEZ; PESSOA, 2011, p. 57). Contudo, é no que tange ao uso de indicadores sociais que nossa crítica ao trabalho dos autores incide.

Ao usar variáveis como o IDH e o IDH-E para criar distritos homogêneos, é gerado um efeito não desejável de criar distritos com composições sociais opostas entre si: distritos de municípios com IDH elevado e distritos com municípios de IDH baixo. Esse processo de separação de tipos de municípios pode ser danoso para o sistema político, pois, no limite, são separados os municípios mais desenvolvidos dos menos desenvolvidos, o que pode acarretar problemas para a criação e a manutenção de programas de redistribuição de bens e riquezas.

Objetivando evitar um efeito semelhante, optamos por desenhar os distritos eleitorais a partir de recortes territoriais já estabelecidos, guardando a coerência geográfica com base tanto na contiguidade territorial como no respeito à coesão regional das unidades, reforçada pelo fato de esses recortes serem empregados também no desenho de políticas públicas (CAZZOLATO, 2009). Os critérios de delimitação dos novos distritos, para ambos os casos, encontram-se expostos em detalhe no Anexo 2. Por ora cabe reforçar que, aceitando que a representação se dá também sobre bases territoriais, a coesão das unidades territoriais foi o critério utilizado para a criação dos novos distritos eleitorais.

\section{Exercício 1}

Redesenhando o mapa eleitoral de São Paulo

Para São Paulo, utilizamos como base as Regiões Administrativas (RAs), as Regiões de Governo (RGs) e as Regiões Metropolitanas (RMs). O uso dessas regiões nos proporcionou três vantagens - uma técnica e duas substantivas. A vantagem técnica foi que, apesar de terem sido realizados alguns ajustes no desenho das regiões para utilizálas como distritos eleitorais, apenas o município de São Paulo precisou ser dividido por conta do tamanho de sua população. Por sua vez, as substantivas foram que como as regiões têm, no mínimo, 30 anos e são utilizadas amplamente para o planejamento e a execução das políticas do governo do estado, eliminamos a possibilidade de empregarmos um critério que a priori favorecesse algum partido.

Essa divisão resultou em 16 novos distritos eleitorais, sendo quatro originários da divisão do município de São Paulo, três da divisão do restante da Região Metropolitana (RM) de São Paulo, oito da fusão de RAs e dois mantendo as RMs de Campinas e da Baixada Santista. O menor distrito, Marília, ficou com aproximadamente 1,8 milhão de habitantes e o maior, Campinas, com 4 milhões ${ }^{2}$. A Figura 1 apresenta os 16 distritos eleitorais, enquanto a Tabela 1 traz a distribuição da população paulista entre os distritos e a respectiva magnitude de cada um dentro da nova configuração:

\footnotetext{
${ }^{2}$ Ver os Anexos para detalhes sobre o processo de desenho dos distritos eleitorais.
} 
Figura 1

Estado de São Paulo dividido em 16 distritos eleitorais

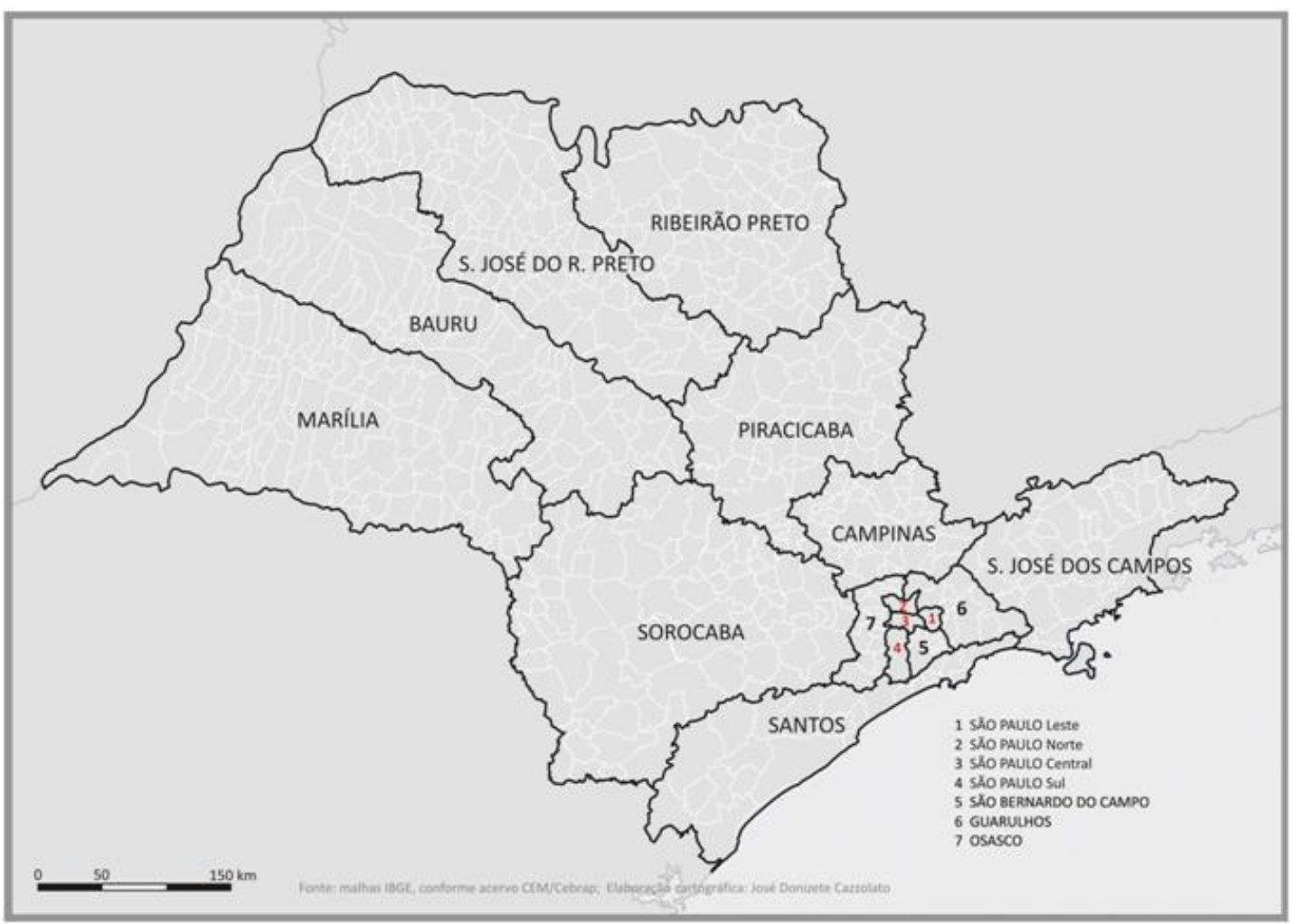

Fonte: Elaboração própria, com base em dados do IBGE. 
SILVA, P. et al. Reforma política no Brasil: indagações sobre o impacto no sistema...

Tabela 1

População e magnitude dos distritos eleitorais de São Paulo

\begin{tabular}{|c|c|c|c|}
\hline Distrito eleitoral & População & (\%) & Magnitude \\
\hline Campinas & 4.0491 .44 & 9,8 & 7 \\
\hline São Paulo Central & 3.386 .339 & 8,2 & 6 \\
\hline Osasco & 3.134 .460 & 7,6 & 5 \\
\hline São Paulo Leste & 2.861 .157 & 6,9 & 5 \\
\hline Sorocaba & 2.804 .662 & 6,8 & 5 \\
\hline São Paulo Sul & 2.782 .341 & 6,7 & 5 \\
\hline Guarulhos & 2.744 .618 & 6,7 & 5 \\
\hline Piracicaba & 2.584 .169 & 6,3 & 4 \\
\hline São Bernardo do Campo & 2.549 .135 & 6,2 & 4 \\
\hline Ribeirão Preto & 2.374 .217 & 5,8 & 4 \\
\hline São José dos Campos & 2.262 .723 & 5,5 & 4 \\
\hline São Paulo Norte & 2.214 .532 & 5,4 & 4 \\
\hline São José do Rio Preto & 2.007 .942 & 4,9 & 3 \\
\hline Santos & 1.932 .406 & 4,7 & 3 \\
\hline Bauru & 1.789 .945 & 4,3 & 3 \\
\hline Marília & 1.774 .370 & 4,3 & 3 \\
\hline
\end{tabular}

Fonte: Elaboração própria com base em dados do IBGE.

Após desenharmos os distritos, realizamos duas simulações com base nos resultados da eleição de 2010 para a Câmara dos Deputados. Na primeira simulação utilizamos as coligações eleitorais e comparamos os resultados obtidos com os oficiais. Nossa opção por utilizar a coligação se deu pela inviabilidade de distribuir as cadeiras entre os partidos coligados. Conforme pontuado, no Brasil a ordenação dos candidatos na lista partidária não é prévia e dependerá da votação nominal de cada um deles. Dada a impossibilidade de saber em qual dos distritos cada partido da coligação lançaria candidatos, optamos por apresentar os resultados por coligação. O Gráfico 1 apresenta o comparativo entre o resultado oficial e a simulação: 
Gráfico 1

Simulação com coligações (São Paulo, 2010)

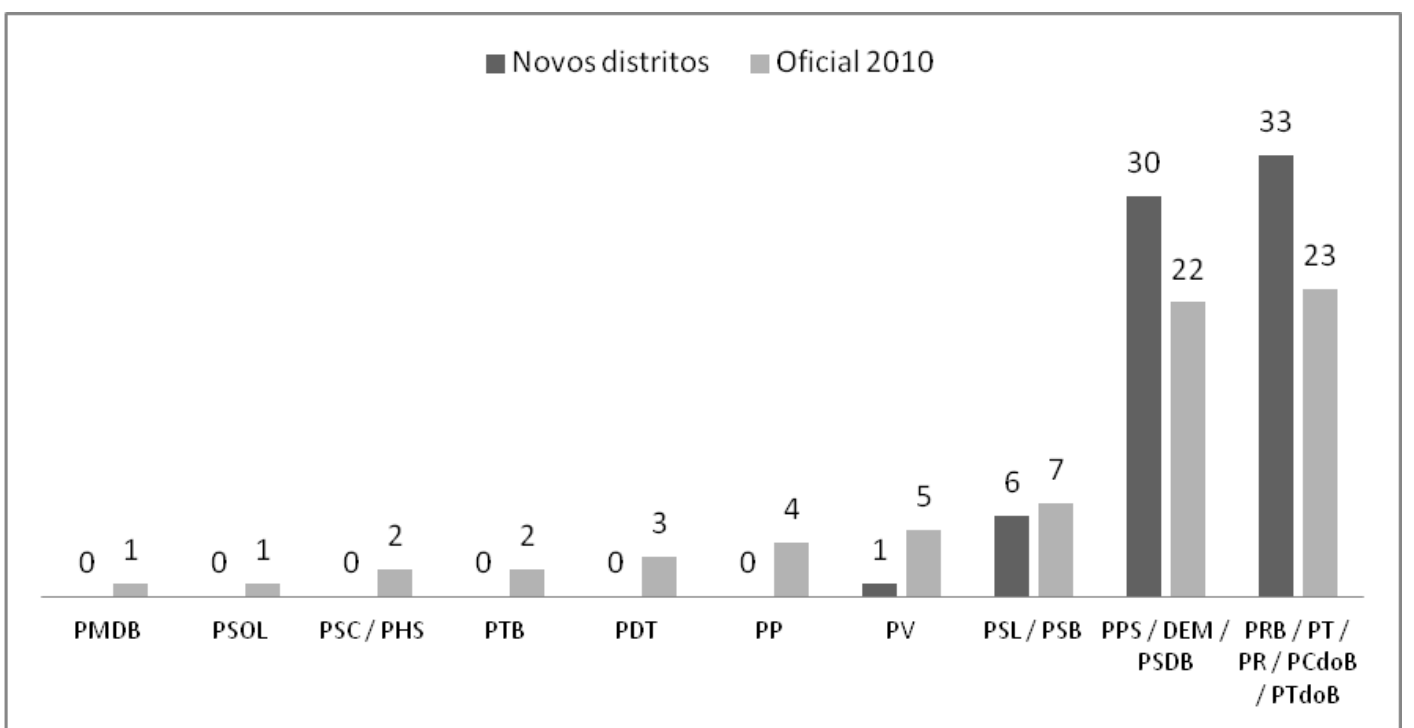

Fonte: Elaboração própria com base em dados do TSE.

Observa-se que as coligações que sairiam beneficiadas pela mudança proposta seriam as coligações dos dois partidos que hoje polarizam a disputa eleitoral no Brasil: PT e PSDB. A coligação petista ganharia dez cadeiras, enquanto a peessedebista, oito. Todas as demais coligações e partidos que concorressem sozinhos perderiam cadeiras.

Já no segundo exercício com os distritos eleitorais, simulamos os resultados desconsiderando as coligações. Com esse cenário buscamos observar o efeito de uma mudança caso fossem utilizados os novos distritos e também proibidas as coligações. A fim de comparação, apresentamos os resultados da simulação juntamente com o resultado oficial, ou seja, com o número de cadeiras conquistadas por cada partido após a distribuição ter sido realizada dentro das coligações. Também apresentamos uma comparação com o resultado para a simulação por partido mantendo o desenho do distrito atual $(\mathrm{M}=$ 70) sem coligações. 
SILVA, P. et al. Reforma política no Brasil: indagações sobre o impacto no sistema...

Gráfico 2

Simulações por partido sem coligação (São Paulo, 2010)

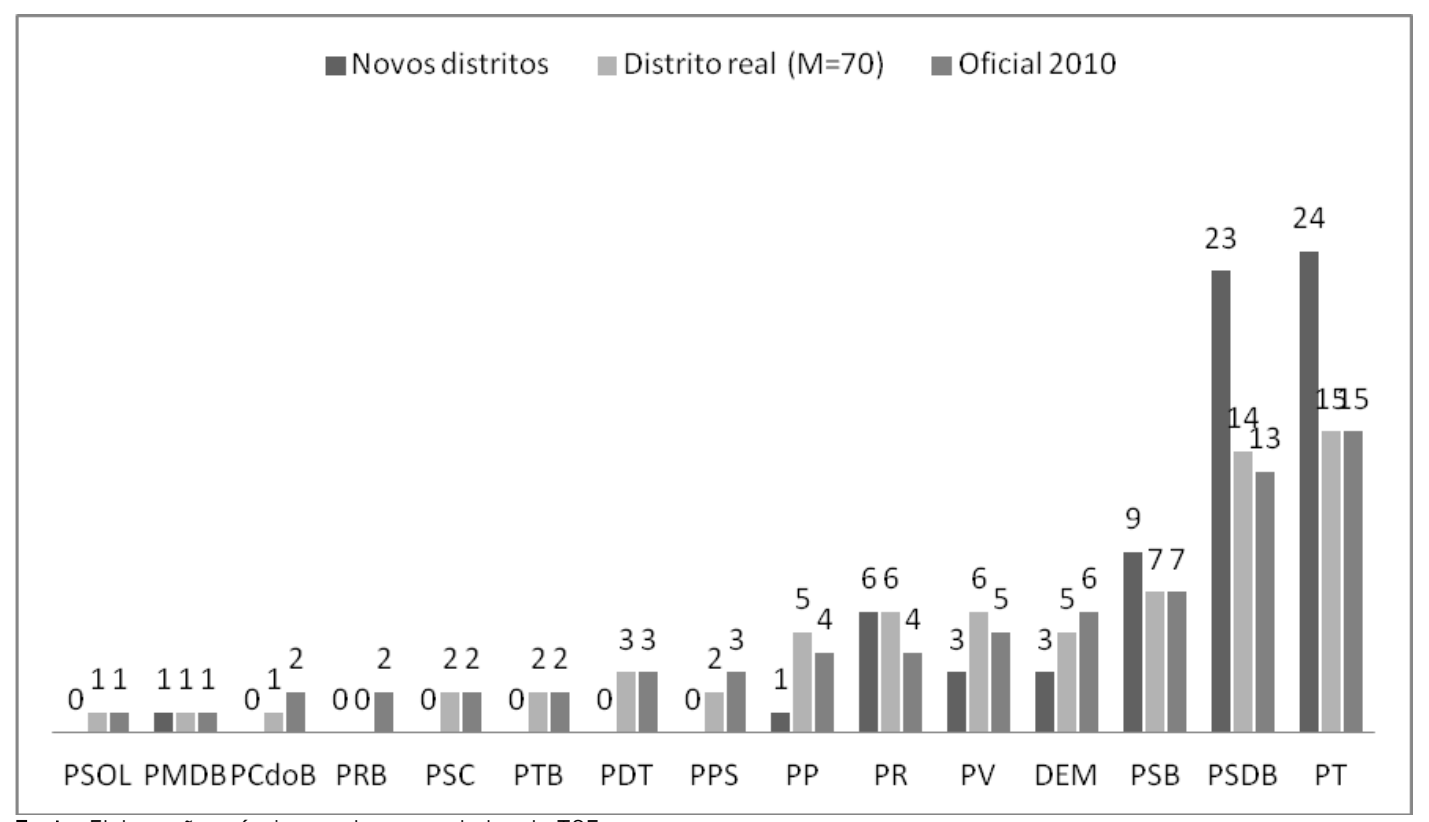

Fonte: Elaboração própria com base em dados do TSE.

O exame do Gráfico 2 revela que a diferença entre o número de cadeiras obtidas no sistema atual e em cenário no qual as coligações fossem proibidas não seria grande. Grosso modo, o número de cadeiras varia em uma unidade, seja para mais ou para menos; a exceção é o PR, que teria um aumento de duas cadeiras em sua bancada, caso os partidos fossem proibidos de competir coligados.

Por sua vez, a simulação utilizando distritos de menor magnitude aponta que, de modo muito mais pronunciado, os maiores partidos seriam beneficiados no caso de uma reforma política que desenhasse distritos semelhantes aos propostos neste artigo. 0 número de partidos efetivos no estado passaria de 8,5 para quatro. PT e PSDB receberiam um incremento de nove e dez cadeiras, respectivamente, enquanto todos os demais partidos teriam suas bancadas diminuídas - sendo que sete partidos deixariam de figurar na composição da bancada paulista. As exceções seriam o PSB e o PR, que receberiam mais duas cadeiras cada, e o PMDB, que conservaria suas cadeiras em todos os casos.

É importante observar que, no caso de uma mudança para distritos semelhantes aos apresentados, um efeito esperado seria que a polarização PT x PSDB - que rege a disputa presidencial e que alguns autores têm apontado como os polos nas disputas de prefeituras no estado de São Paulo (LIMONGI; DAVIDIAN; MESQUITA, 2009) - tornar-se-ia aguda também nas eleições para a Câmara dos Deputados, de modo que a vantagem desses dois partidos aumentaria ainda mais. A título de exemplificação desse efeito, no Gráfico 3 podemos observar a distribuição das cadeiras entre PT, PSDB e os demais partidos: 
Gráfico 3

Partidos nos novos distritos (São Paulo, 2010)

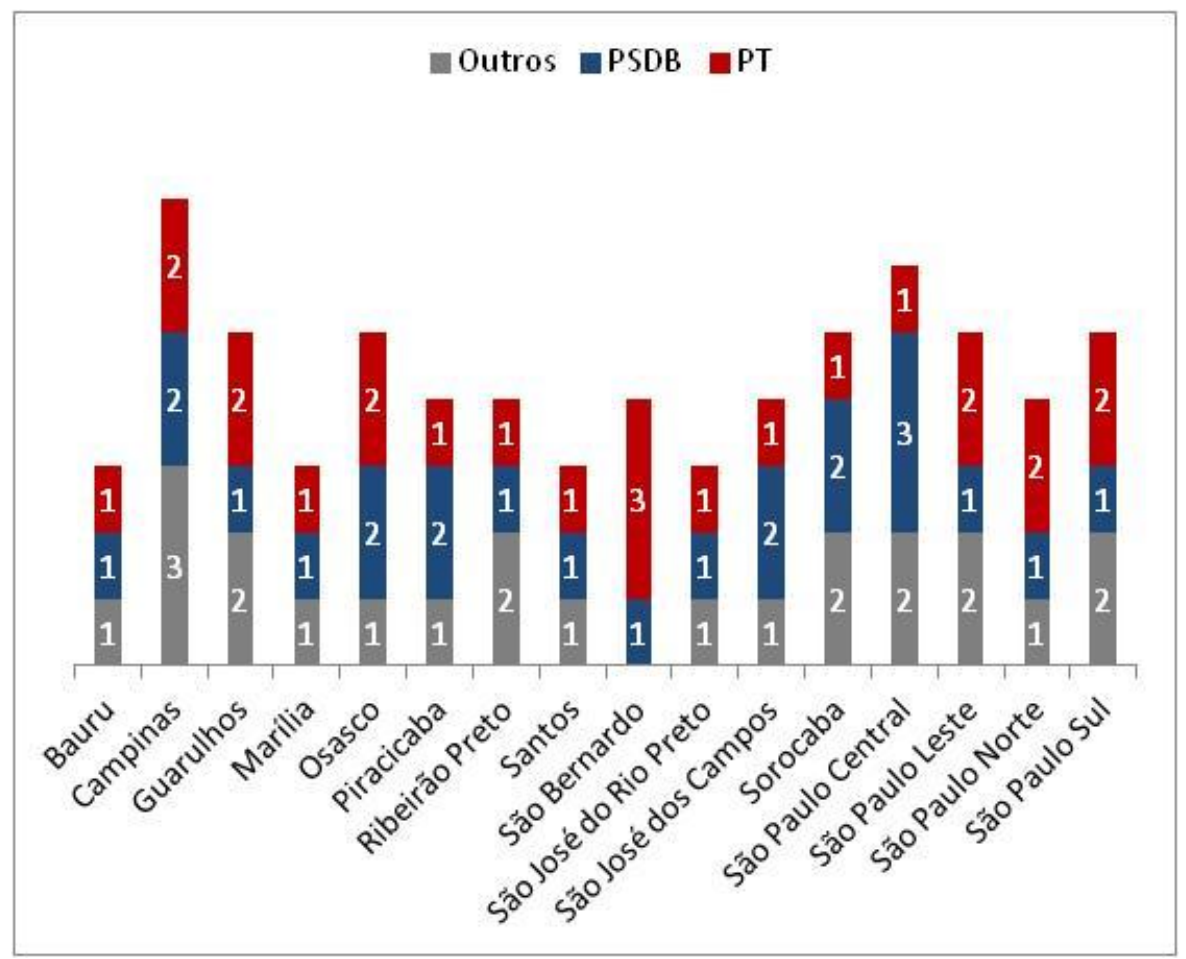

Fonte: Elaboração própria, com base em dados do TSE.

É notável que PT e PSDB seriam os únicos partidos que conseguiriam cadeiras em todos os 16 distritos. A polarização se acentuando com a adoção de um sistema de distritos com magnitude baixa, é factível supor que as campanhas de um menor número de candidatos tornar-se-iam mais centradas no partido $^{3}$. Ou seja, a despeito da representação de lista aberta, o efeito da reputação pessoal seria diminuído vis-à-vis o efeito da reputação partidária ${ }^{4}$. De outro lado, a relação político-eleitor estreitar-seia. Isso ocorreria também em função da redução do número de concorrentes, o que poderia acarretar na redução da incerteza da continuidade da carreira política - um dos argumentos levantados por Cheibub (2007). Isto é, dado o menor número de candidaturas, e dado que a disputa aconteceria em uma área de

\footnotetext{
${ }^{3}$ Cabe destacar que esse argumento pode ser aplicado mesmo se as coligações não fossem proibidas. Todavia, nesse caso, a polarização poderia dar-se entre dois blocos de partidos, os de "centro-esquerda" e os de "centro-direita".

${ }^{4}$ Shugart e Carey (1992) argumentam que, em sistemas de representação proporcional, a magnitude opera como um condutor para a importância da reputação pessoal. Isto é, em sistemas de RP, quanto maior a magnitude mais importante torna-se a reputação pessoal para a eleição. Ao discutir esse argumento, Cheibub (2008) aponta que, mesmo em sistemas em que a reputação pessoal é teoricamente importante, eleitores tendem a votar com base na sigla partidária. Como evidência a esse argumento, Cheibub aponta autores que afirmam que, ao mudar de partido, o parlamentar não carrega seus votos. Ao argumentarmos que, com distritos menores, a reputação partidária passaria a ser mais importante para a eleição, não estamos desconsiderando nenhuma das ponderações; nosso argumento reside no fato de a eleição proporcional se aproximar da lógica do sistema majoritário.
} 
menor circunscrição, um efeito esperado é a aproximação entre o candidato e o eleitor, favorecendo a accountability vertical do sistema político.

Outro efeito possível é o da perpetuação das elites políticas. Cabe ressaltar que esse ponto relaciona-se com o anterior (diminuição da incerteza da eleição), no entanto, outra consideração diz respeito à dimensão geográfica desigual dos distritos eleitorais. É esperado que, em distritos com áreas maiores, a campanha seja mais cara, em razão do deslocamento que os candidatos têm que fazer, do que em distritos com área menor. Ou seja, o custo para competir em distritos do interior seria mais elevado do que nos distritos com maior grau de urbanização. Assim, candidatos advindos de famílias tradicionais poderiam se beneficiar de uma mudança como a apresentada ${ }^{5}$.

\section{Exercício 2}

Redesenhando o mapa eleitoral: o caso de Pernambuco

Para Pernambuco, partimos dos recortes mais tradicionais de regionalização dos estados do Nordeste oriental, que se embasa na conformação macroambiental da Zona da Mata, Agreste e Sertão. Havendo, contudo, uma grande concentração demográfica no entorno metropolitano do Recife, optamos por uma adaptação dos recortes tradicionais, atentando para os critérios de conformação da rede urbana.

No caso de Pernambuco, obtivemos seis distritos eleitorais, sendo três no litoral (Região Metropolitana de Recife, Zona da Mata Norte e Sul) e três nos domínios do Agreste e Sertão, conforme exibe a Figura 2. A Tabela 2, por sua vez, traz a distribuição da população pelos distritos e a magnitude correspondente de cada um:

\footnotetext{
${ }^{5}$ Agradecemos a Ricardo Ceneviva por nos ter apontado esse efeito.
} 
Figura 2

Estado de Pernambuco dividido em seis distritos eleitorais

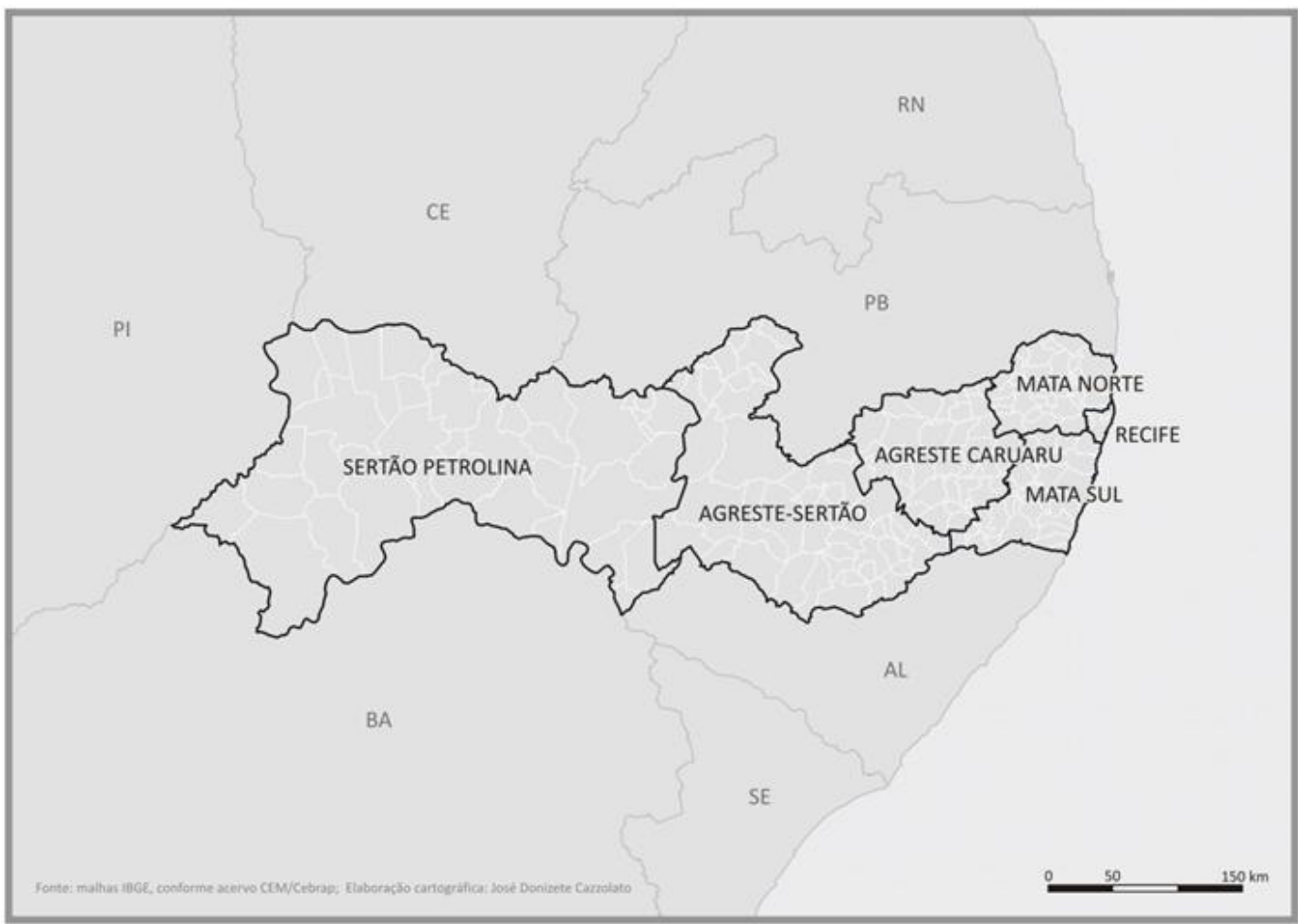

Fonte: Elaboração própria, com base em dados do IBGE.

Tabela 2

População e magnitude dos distritos eleitorais de Pernambuco

\begin{tabular}{|l|c|c|c|}
\hline \multicolumn{1}{|c|}{ Distrito eleitoral } & População & (\%) & Magnitude \\
\hline Recife & 2.363 .045 & 26,9 & 7 \\
\hline Mata Sul & 1.644 .749 & 18,7 & 5 \\
\hline $\begin{array}{l}\text { Agreste de } \\
\text { Caruaru }\end{array}$ & 1.230 .196 & 14,0 & 4 \\
\hline $\begin{array}{l}\text { Sertão de } \\
\text { Petrolina }\end{array}$ & 1.193 .700 & 13,6 & 3 \\
\hline Agreste do Sertão & 1.188 .420 & 13,5 & 3 \\
\hline Mata Norte & 1.176 .338 & 13,4 & 3 \\
\hline
\end{tabular}

Fonte: Elaboração própria com base em dados do IBGE. 
Assim como para São Paulo, realizamos duas simulações com base nos resultados da eleição de 2010 para a Câmara dos Deputados. O Gráfico 4 apresenta o comparativo entre o resultado oficial e a simulação para os votos por coligação:

\section{Gráfico 4}

Simulação com coligações (Pernambuco, 2010)

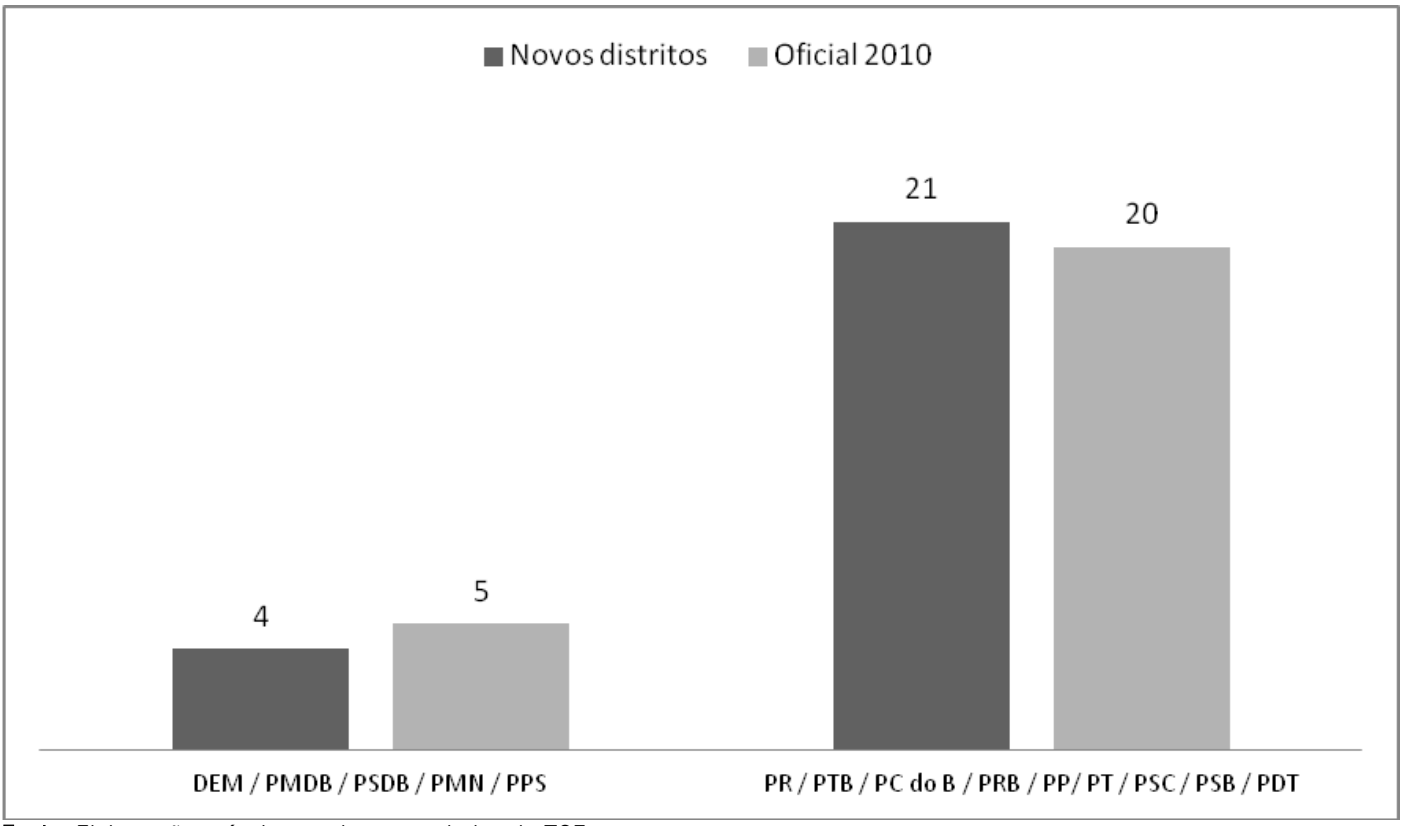

Fonte: Elaboração própria com base em dados do TSE.

Apenas duas coligações conquistam cadeiras em 2010. A vencedora, cujo partido com melhor desempenho é o PSB, se beneficiaria passando de 20 a 21 cadeiras, enquanto a liderada pelo PSDB perderia uma cadeira, passando a ocupar quatro cadeiras na Câmara. Em termos substantivos, o resultado da simulação revela que, tal como para o caso de São Paulo, a maior coligação seria beneficiada caso o estado fosse dividido em distritos; o uso de distritos também favorece o(s) maior(es) partido(s) no estado, como se evidenciará a seguir.

O segundo exercício, por sua vez, simulou os resultados desconsiderando as coligações, tanto para os distritos criados, como para o distrito atual, cuja magnitude é 25. O exame do Gráfico 5 revela que o PSB, maior partido do estado, seria o maior beneficiado em ambos os cenários simulados. Na ausência de coligações, o partido seria favorecido de ambas as formas, seja no distrito eleitoral atual, seja no redesenho proposto - beneficiando-se, sobremaneira, no segundo caso, no qual mais do que duplicaria seu total de cadeiras. Em sentido inverso ao do PSB, o PTB teria a maior perda de cadeiras, 
passando de quatro (no modelo atual) para uma (no distrito atual sem coligação). Já considerando os novos distritos, o partido tem sua bancada reduzida pela metade.

Gráfico 5

Simulações por partido sem coligação (Pernambuco, 2010)

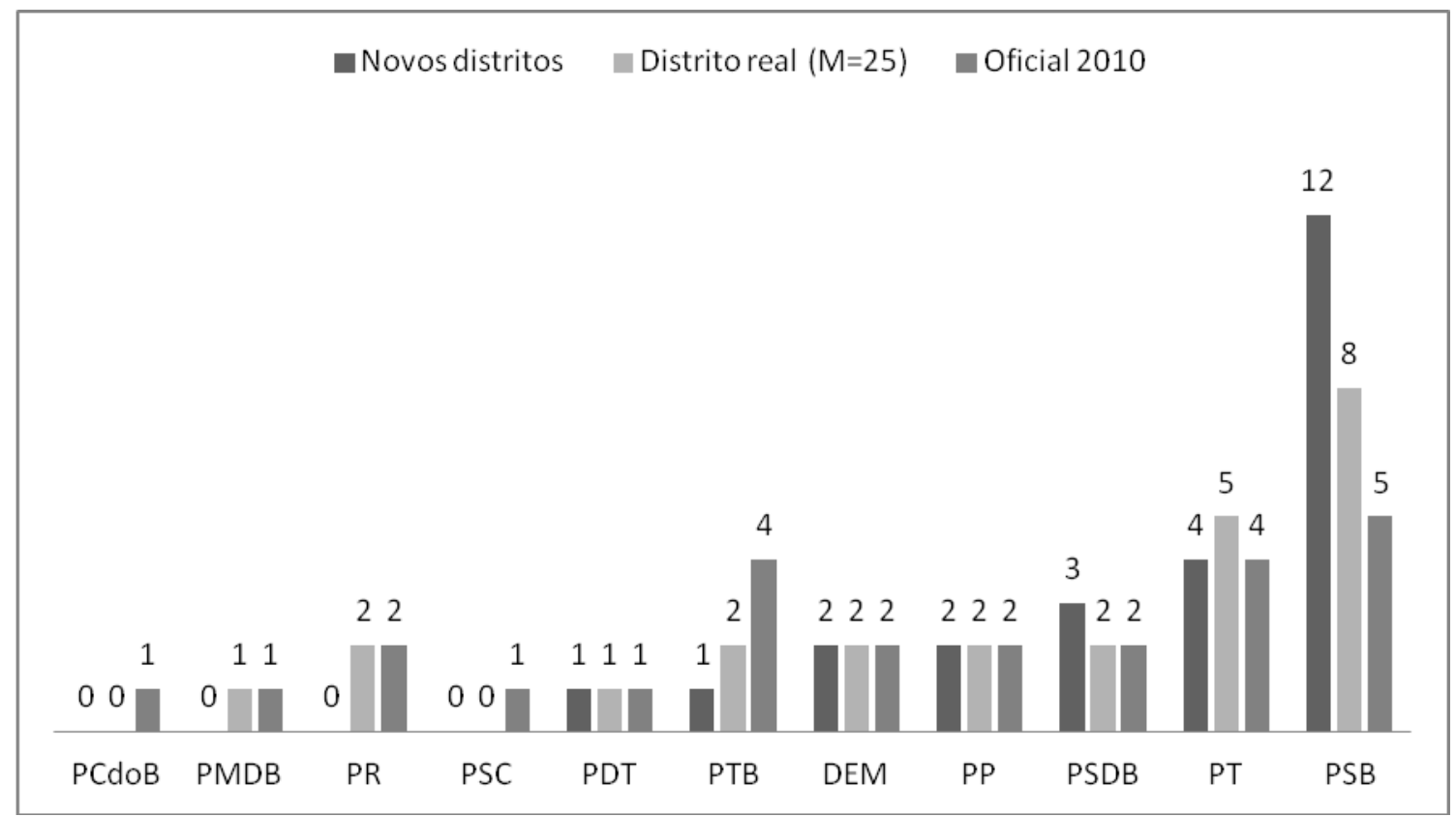

Fonte: Elaboração própria com base em dados do TSE.

Para os demais partidos, assim como em São Paulo, as variações seriam menos acentuadas nos dois novos cenários, com variações de uma unidade no total de cadeiras conquistadas. Dos partidos a lançar candidato no estado, três não teriam seus resultados impactados em nenhum dos cenários propostos. Eliminando-se as coligações no distrito atual, dois partidos perderiam sua representação na bancada pernambucana na Câmara. Abolindo-se as coligações e redesenhando os distritos, outros dois ficariam sem cadeiras, de modo que o número de partidos efetivos passaria de 8,1 a 3,5. Ou seja, a criação dos distritos eleitorais impactaria de maneira mais pronunciada o cenário político pernambucano, tanto na diminuição do número de siglas como em benefício do maior partido, o PSB, que seria o único a eleger representante em todos os distritos criados, conforme revela o Gráfico 6 : 
Gráfico 6

Partidos nos novos distritos (Pernambuco, 2010)

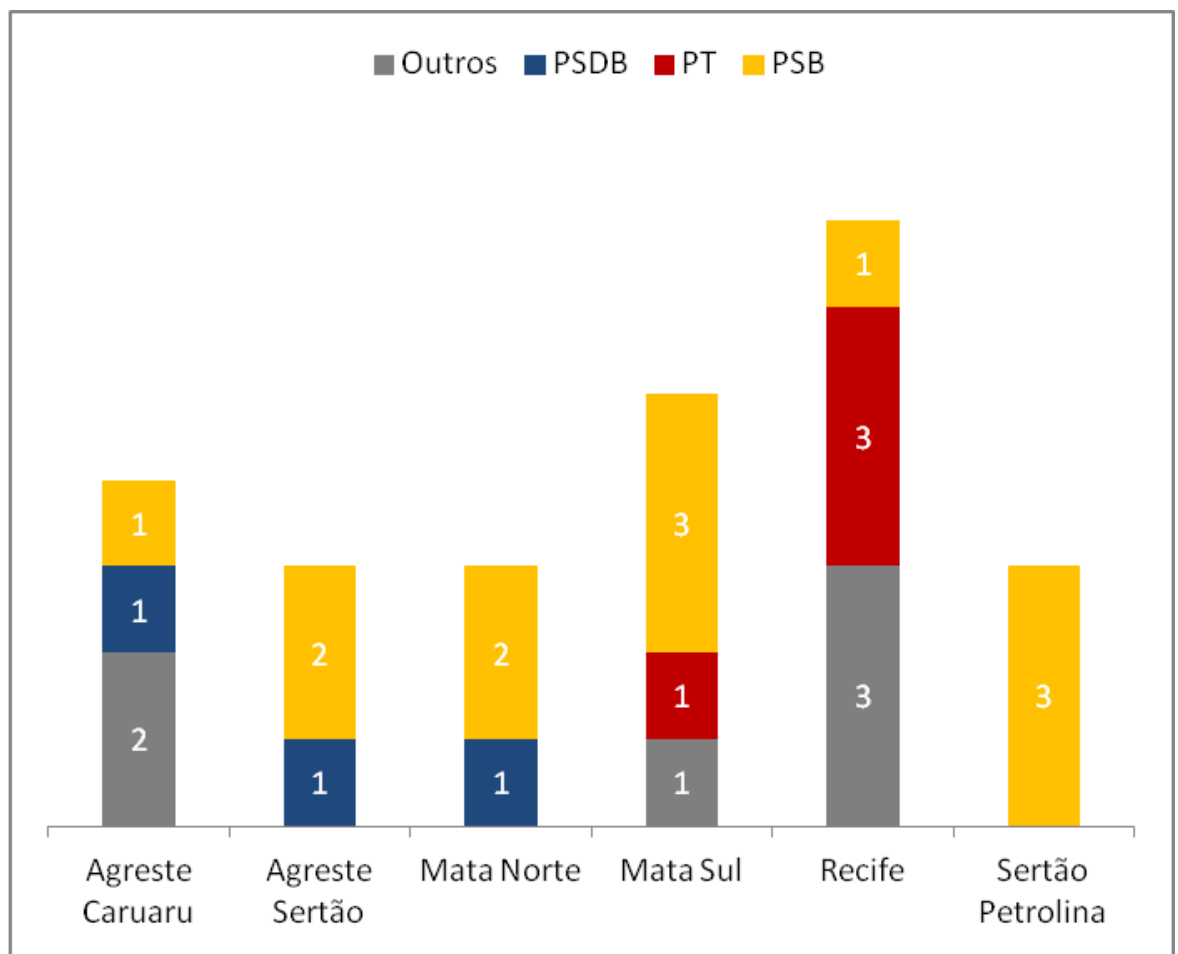

Fonte: Elaboração própria, com base em dados do TSE.

\section{Considerações Finais}

Neste artigo buscamos trabalhar com alguns aspectos da crítica feita às regras eleitorais para as disputas legislativas no Brasil. O único aspecto que não foi possível explorar com as simulações, evidentemente, foi a lista fechada. A esse respeito, contudo, conforme pontuado nessa revisão, uma série de trabalhos tem buscado mitigar as asserções tradicionais em torno do emprego da lista aberta, identificando as respostas estratégicas de que os partidos lançam mão diante dos incentivos do arranjo institucional.

O fim das coligações, por sua vez, não alterou radicalmente a distribuição de cadeiras entre os partidos. $O$ argumento de que as coligações favorecem em demasia os partidos menores, tornando a representação desproporcional e contribuindo com a fragmentação partidária, não encontra muito suporte nos dados. Supõe-se, entretanto, que no longo prazo esses efeitos seriam cumulativos, o que poderia acarretar a eliminação dos competidores que têm suas bancadas enfraquecidas progressivamente na Câmara - mas isso é algo que o exercício não nos permite captar, já que a simulação parte de resultados dados, pressupondo assim condições constantes. 
Nesse sentido, merece destaque o fato de que, como em toda simulação que utiliza dados do passado para desenhos institucionais hipotéticos, os resultados não permitem afirmar qual seria o comportamento real dos agentes em resposta a uma mudança. Como observamos nos exercícios em que utilizamos os novos distritos tanto com as coligações quanto com os partidos como unidade de agregação dos votos, os maiores competidores se beneficiam. Entretanto, assumindo que os partidos têm algum papel na organização da lista e, mais do que isso, levam em conta tanto a dimensão territorial como a diversidade social dos candidatos, conforme sugere Nicolau (2006), há de se supor que eles redesenhariam suas estratégias diante da nova configuração. Por exemplo, é razoável supor que, com a reforma proposta, partidos de menor relevo no estado priorizariam lançar candidaturas nos distritos onde calculam ter maior viabilidade eleitoral, ao passo que partidos com votos distribuídos por todo o estado - como o PT e o PSDB para o caso paulista e o PSB para o pernambucano - poderiam ter como estratégia lançar candidatos em todos os distritos.

Por ora, a simulação que utiliza distritos eleitorais de menor magnitude revelou que as maiores chapas seriam beneficiadas no caso de uma reforma semelhante à proposta neste artigo, e a configuração das disputas se aproximaria à dos cargos majoritários. Se há quem defenda a diminuição do número de partidos por conta da maior inteligibilidade do sistema, a diminuição da magnitude dos distritos somada à eliminação das coligações contemplaria esse anseio. À exceção de quatro partidos, todos os demais perderiam cadeiras em São Paulo, cuja bancada passaria a ser composta por praticamente metade dos partidos representados atualmente. Em Pernambuco, 4 dos 11 partidos deixariam de estar representados na bancada do estado.

Nesse mesmo sentido, se a competitividade se atenua nesse contexto pela diminuição do número de candidatos, conforme aponta Cheibub, imagina-se que a contrapartida seria a maior austeridade dos partidos no que diz respeito à entrada de candidatos na lista. A lista aberta assumiria um aspecto mais "fechado", por assim dizer. Em uma palavra, maior poder aos líderes partidários. A questão é até onde a ampliação desse poder vai ao encontro das alterações aspiradas.

Cabe indagar, por fim, o quanto essas mudanças incentivariam o fortalecimento dos partidos isso se aceitarmos que estes já não são suficientemente fortes - ou o quanto simplesmente acirrariam o fechamento das disputas, aumentando ainda mais o poder das mesmas elites que já dominam atualmente o jogo político. Antes, ainda, cabe indagar o que se entende - ou se espera - por força dos partidos políticos.

\section{Referências Bibliográficas}

AMES, B. "Electoral strategy under open-list proportional representation". American Journal of Political Science, vol. 39, $\mathrm{n}^{\circ} 2$, p. 406.433, 1995.

The deadlock of democracy in Brazil. Ann Arbor: University of Michigan Press, 2001.

Amorim Neto, O.; Cortez, B.; PessoA, S. "Redesenhando o mapa eleitoral do Brasil: uma proposta de reforma política incremental". Opinião Pública, Campinas, vol. 17, n 1, p. 45-75, jun. 2011.

Amy, D. Real choices/New Voices: how proportional representation elections could revitalize American democracy, $2^{\mathrm{a}}$ ed. New York: Columbia University Press, 2002. 
ARAto, A. "Representação, soberania popular e accountability”. Lua Nova, São Paulo, n 55·56, p. 85-103, 2002.

BRAGA, M. S. "Organizações partidárias e seleção de candidatos no estado de São Paulo". Opinião Pública [online], vol. $14, \mathrm{n}^{\circ} 2$, p. 454.485, 2008.

CAREY, J.; HIX, S. "The electoral sweet spot: low-magnitude proportional electoral systems". American Journal of Political Science, Houston, vol. 55, n² 2, April, 2011.

Cazzolato, D. "Geografia, território e gestão: contribuição ao debate sobre a regionalização do SUS". In: II Congresso Internacional e IV Simpósio Nacional de Geografia da Saúde - Geosaúde, Uberlândia, 2009.

CheibuB, J. A. "Political reforms in Brazil: diagnosis, recent proposals and a suggestion". In: Conference "Brazil: President Lula's First Administration", University of Illinois at Urbana-Champaign, April, 2007.

"Political reforms in Brazil: diagnosis, recent proposals and a suggestion. In: BAER, W.; Love, J. (eds.). Brazil under Lula: an assessment of the worker-president's first administration. New York: Palgrave Macmillan, 2008.

CINTRA, A. O. Majoritário ou proporcional? Em busca do equilíbrio de um sistema eleitoral. In: FLEISCHER, D. Reforma política, agora vai?. Cadernos Adenauer, vol. 2. Rio de Janeiro: Konrad Adenauer Stiftung Brasil, 2005.

DUVERGER, M. Os partidos políticos. $2^{\mathrm{a}}$ ed. Rio de Janeiro: Zahar, 1987.

ElSTER, J. "Forces and mechanisms in the Constitution-making process". Duke Law Journal, Durham, vol. 45, nº 2, 2008.

FIgueIRedo, A.; LImongl, F. Executivo e Legislativo na nova ordem constitucional. Rio de Janeiro: Editora FGV, 1999.

FleisCheR, D. "Sistema partidário brasileiro: 1945-1997". Política Comparada, vol. 1, nº 2, 1997.

KInzo, M. "Partidos, eleições e democracia no Brasil pós-1985". Dados - Revista Brasileira de Ciências Sociais, São Paulo, vol. 19, fev. 2004.

LaAkso, M.; TAagepera, R. "The 'effective' number of parties: a measure with application to West Europe". Comparative Political Studies, University of Washington, vol. 12, $\mathrm{n}^{\circ} 1,1973$.

LAMOUNieR, B. A democracia brasileira de 1985 à década de 1990: a síndrome da paralisia hiperativa. In: Velloso, J. Governabilidade, sistema político e violência urbana. Rio de Janeiro: José Olympio, 1994.

LIMONGI, F.; Davidian, A.; MesQUITA, L. "Eleições em São Paulo: relacionando as esferas estadual e municipal". In: XXXIII Encontro Nacional da Anpocs, Minas Gerais, 2009.

MaInWARING, S. "Políticos, partidos e sistemas eleitorais". Novos Estudos, n² 29, p. 34-58, São Paulo, 1991. Press, 1999.

Rethinking party system in the third wave of democratization: the case of Brazil. Stanford: Stanford University

Nicolau, J. "O sistema eleitoral de lista aberta no Brasil". Dados - Revista de Ciências Sociais, vol. 49, n 4, Rio de Janeiro, 2006.

POWELL JR., B.; WHITTEN, G. "A cross-national analysis of economic voting: taking account of political context". American Journal of Political Science, Houston, $n^{\circ}$ 37, p. 391-414, 1993.

Santos, F. "Instituições eleitorais e desempenho do presidencialismo no Brasil". Dados - Revista de Ciências Sociais, vol. 42, n 1 , p. $111 \cdot 138,1999$.

SANTOS, W. Crise e castigo: partidos e generais na política brasileira. Rio de Janeiro: Vértice, 1987.

Shugart, M.; CareY, J. Presidents and assemblies. New York: Cambridge University Press, 1992.

SILVA, G.; MesouitA, L.; Davidian, A. "Partidos e eleições proporcionais: uma análise exploratória das estratégias partidárias nas eleições proporcionais". In: Seminário Internacional Instituições, Comportamento Político e Geografia do Voto. Brasília, 2012.

SIMONI JR., S.; SILVA, P.; SoUZA, R. Sistema eleitoral na ANC 1987-1988: a manutenção da representação proporcional. In: Carvalho, M.; Araújo, C.; SimÕes, S. A Constituição de 1988: passado e futuro. São Paulo: Hucitec, 2009.

URBInATI, N. Representative democracy, principles and genealogy. Chicago: University of Chicago Press, 2006. 
OPINIÃO PÚBLICA, Campinas, vol. $21, n^{\circ} 1$, abril, 2015, p. 1-32

Anexo 1

Tabela 3

Lista dos partidos

\begin{tabular}{|c|c|c|c|c|c|}
\hline Registro & Sigla & Nome & $\begin{array}{l}\text { Registro } \\
\text { definitivo } \\
\text { no TSE }\end{array}$ & Transições da sigla & Histórico \\
\hline 25 & DEM & Democratas & 2007 & PFL $>$ DEM & $\begin{array}{l}\text { Nova denominação do } \\
\text { PFL (Partido da Frente } \\
\text { Liberal). }\end{array}$ \\
\hline 10 & PRB & $\begin{array}{c}\text { Partido Republicano } \\
\text { Brasileiro }\end{array}$ & 2005 & PMR $>$ PRB & $\begin{array}{l}\text { Nova denominação do } \\
\text { PMR (Partido } \\
\text { Municipalista } \\
\text { Renovador). }\end{array}$ \\
\hline 11 & PP & Partido Progressista & 2003 & $P D S>P P R>P P B>P P$ & $\begin{array}{c}\text { Nova denominação do } \\
\text { PPB (Partido } \\
\text { Progressista Brasileiro), } \\
\text { cuja origem é o PDS } \\
\text { (Partido Democrático } \\
\text { Social). } \\
\end{array}$ \\
\hline 12 & PDT & $\begin{array}{c}\text { Partido Democrático } \\
\text { Trabalhista } \\
\end{array}$ & 1981 & & \\
\hline 13 & PT & $\begin{array}{c}\text { Partido dos } \\
\text { Trabalhadores }\end{array}$ & 1982 & & \\
\hline 14 & PTB & $\begin{array}{c}\text { Partido Trabalhista } \\
\text { Brasileiro }\end{array}$ & 1981 & & \\
\hline 15 & PMDB & $\begin{array}{l}\text { Partido do Movimento } \\
\text { Democrático Brasileiro }\end{array}$ & 1981 & & \\
\hline 16 & PSTU & $\begin{array}{c}\text { Partido Socialista dos } \\
\text { Trabalhadores } \\
\text { Unificados }\end{array}$ & 1995 & & \\
\hline 17 & PSL & Partido Social Liberal & 1998 & & \\
\hline 19 & PTN & $\begin{array}{c}\text { Partido Trabalhista } \\
\text { Nacional }\end{array}$ & 1997 & & \\
\hline 20 & PSC & Partido Social Cristão & 1990 & & \\
\hline 21 & PCB & $\begin{array}{c}\text { Partido Comunista } \\
\text { Brasileiro }\end{array}$ & 1994 & & \\
\hline 22 & PR & Partido da República & 2006 & PL+Prona $>$ PR & $\begin{array}{l}\text { Fruto da fusão do PL } \\
\text { (Partido Liberal) com o } \\
\text { Prona (Partido de } \\
\text { Reedificação da Ordem } \\
\text { Nacional). }\end{array}$ \\
\hline 23 & PPS & $\begin{array}{l}\text { Partido Popular } \\
\text { Socialista }\end{array}$ & 1992 & PCB $>$ PPS & $\begin{array}{l}\text { O partido é produto da } \\
\text { dissolução do antigo } \\
\text { PCB. Mantém o número } \\
23 \text {, enquanto o novo PCB } \\
\text { é registrado com número } \\
21 .\end{array}$ \\
\hline 27 & PSDC & $\begin{array}{c}\text { Partido Social } \\
\text { Democrata Cristão }\end{array}$ & 1997 & & \\
\hline 28 & PRTB & $\begin{array}{l}\text { Partido Renovador } \\
\text { Trabalhista Brasileiro }\end{array}$ & 1997 & & \\
\hline 29 & PCO & $\begin{array}{c}\text { Partido da Causa } \\
\text { Operária }\end{array}$ & 1997 & & \\
\hline 31 & PHS & $\begin{array}{l}\text { Partido Humanista da } \\
\text { Solidariedade }\end{array}$ & 2000 & $\mathrm{PSN}>\mathrm{PHS}$ & $\begin{array}{c}\text { Nova denominação do } \\
\text { PSN (Partido Solidarista } \\
\text { Nacional). }\end{array}$ \\
\hline 33 & PMN & $\begin{array}{c}\text { Partido da Mobilização } \\
\text { Nacional }\end{array}$ & 1990 & & \\
\hline
\end{tabular}


SILVA, P. et al. Reforma política no Brasil: indagações sobre o impacto no sistema...

\begin{tabular}{|c|c|c|c|c|c|}
\hline 36 & PTC & $\begin{array}{c}\text { Partido Trabalhista } \\
\text { Cristão }\end{array}$ & 2001 & PJ>PRN>PTC & $\begin{array}{c}\text { Nova denominação do } \\
\text { PRN (Partido da } \\
\text { Reconstrução Nacional), } \\
\text { antigo PJ (Partido da } \\
\text { Juventude). }\end{array}$ \\
\hline 40 & PSB & $\begin{array}{c}\text { Partido Socialista } \\
\text { Brasileiro }\end{array}$ & 1988 & & \\
\hline 43 & PV & Partido Verde & 1993 & & \\
\hline 44 & PRP & $\begin{array}{c}\text { Partido Republicano } \\
\text { Progressista }\end{array}$ & 1991 & & \\
\hline 45 & PSDB & $\begin{array}{c}\text { Partido da Social } \\
\text { Democracia Brasileira }\end{array}$ & 1989 & & \\
\hline 50 & PSOL & $\begin{array}{c}\text { Partido Socialismo e } \\
\text { Liberdade }\end{array}$ & 2005 & & \\
\hline 65 & PCdoB & $\begin{array}{c}\text { Partido Comunista do } \\
\text { Brasil }\end{array}$ & 1989 & & \\
\hline 70 & PTdoB & $\begin{array}{c}\text { Partido Trabalhista do } \\
\text { Brasil }\end{array}$ & 1994 & & \\
\hline
\end{tabular}

Anexo 2

Distritos eleitorais no estado de São Paulo: um ensaio de distritalização

O estado de São Paulo é representado na Câmara por 70 deputados federais, em uma proporção ideal de 590 mil habitantes para cada parlamentar. Apresentamos aqui uma proposta de recorte do território por aglutinação de municípios em novas unidades territoriais que chamamos de distritos eleitorais (DEs).

A divisão foi feita levando em consideração que a organização do espaço se dá a partir de fatores diversos, como a distribuição dos centros urbanos, sua hierarquia combinada à rede viária, os fluxos de pessoas, serviços e mercadorias, os processos históricos e identitários, e, em muitos casos, a geomorfologia ou o ecossistema predominante que definem os nódulos e tramas regionais. Em uma linha, buscou-se a coerência geográfica dos recortes espaciais, com base na contiguidade territorial e respeito às identidades locais.

A atenção à questão regional pode ser o diferencial entre uma divisão geograficamente consistente e uma repartição por mera aglutinação de unidades municipais. Vale insistir na própria conceituação corrente adotada pelos geógrafos para território: porção espacial denominada, delimitada e apropriada, onde florescem ou reforçam-se os laços identitários. A observância a esse preceito geográfico é bastante pertinente na medida em que se busca trabalhar não com porções territoriais aleatórias, mas com um recorte factível baseado em critérios técnicos consistentes. Cremos que, caso uma reforma eleitoral desse tipo fosse aprovada, a operacionalização se daria nesse sentido. Isso colocado, será exposto como chegamos a essa divisão.

Regionalização paulista

Tomamos como ponto de partida as divisões regionais praticadas historicamente no estado. Na passagem das décadas 1960/1970, no entanto, quando o modo ferroviário já perdera a hegemonia, instituiu-se, no âmbito do executivo estadual, uma compartimentação regional calcada nos principais polos urbanos do estado. Denominadas Regiões Administrativas, totalizavam 9 e, pouco tempo depois, passaram a 11. Subdividiam-se em unidades 
denominadas Sub-Regiões Administrativas, mas esse segundo recorte acabou não sendo assimilado. Na década de 1980, surgiu um novo desenho regional, composto de 43 unidades, na dimensão escalar aproximada das referidas sub. regiões. Utilizada por todas as secretarias de estado, acabaram perdendo a força nas gestões seguintes, mas permaneceram como referência técnica. Adequados os perímetros, as RGs (Regiões de Governo) passaram a ser utilizadas como subdivisões das RAs.

Desde o início dos anos 1990, porém, o número de RAs passou para 15, com o desmembramento de Ribeirão Preto (que resultou nas novas RAs de Franca, Barretos e Central) e a criação da RA de Registro. As RGs, por sua vez, mantêm-se com o mesmo número de unidades, como demonstra o mapa da Figura 3:

Figura 3

Estado de São Paulo dividido em RAs e RGs

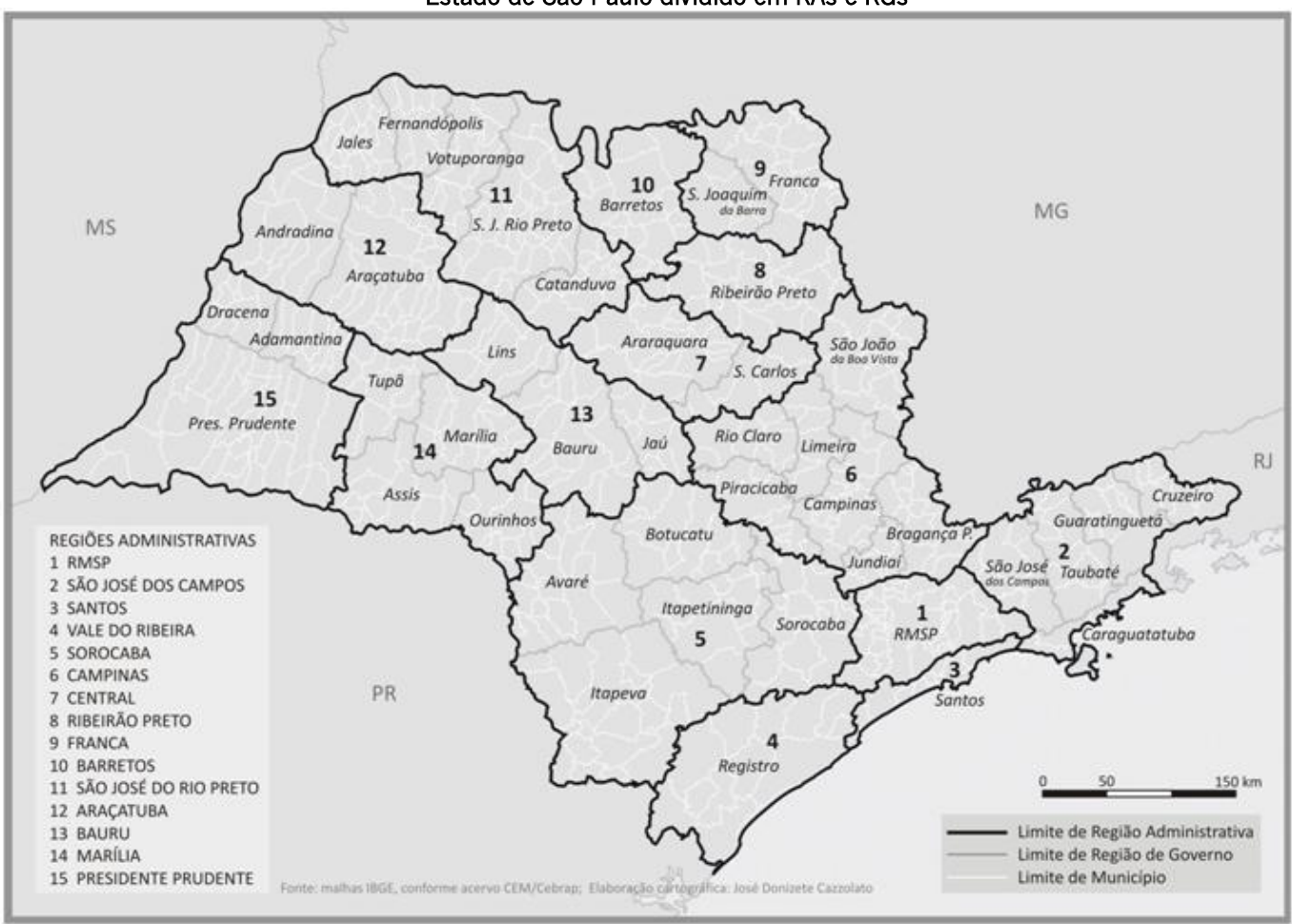

Fonte: Elaboração própria, com base em dados do IBGE.

Dada sua utilização no âmbito do planejamento, entre outras esferas da gestão estadual, as RAs e as RGs seguem reforçando as identidades dos grandes e médios polos urbanos do estado após quatro décadas de utilização. Assim, empregar as RAs como ponto de partida, ou, em alguns casos, as RGs, garantiria o lastro geográfico dos distritos eleitorais propostos.

Uma segunda unidade de regionalização utilizada foi a Região Metropolitana (RM). A RM de São Paulo, instituída no início dos anos 1970, por legislação federal, consagrou o que se conhecia, na época, como Grande São 
Paulo. Seu desenho, inclusive, foi integralmente contemplado pela estrutura regional acima referida: há uma RG e uma RA coincidentes com a RMSP. O mesmo ocorre com a RM da Baixada Santista.

Distritos eleitorais

A primeira formatação de divisão do estado de São Paulo em distritos eleitorais foi o próprio desenho das divisões acima expostas. Consideradas as RGs, obtém-se um total de 43 distritos eleitorais, variando o número de habitantes entre 108 mil e 19,6 milhões. Todavia, tais recortes não atenderiam à demanda da pesquisa, pelo número de unidades e pela defasagem existente entre os valores de população. Partiu-se, então, para o recorte das RAs, que resultam no seguinte quadro: 15 unidades, variando entre 269 mil (Registro) e 19,6 milhões de habitantes (São Paulo), com a mediana em 1,0 milhão (Bauru), como se vê na Figura 4:

Figura 4

Distribuição da população nos distritos eleitorais coincidentes com os perímetros das RAs (São Paulo)

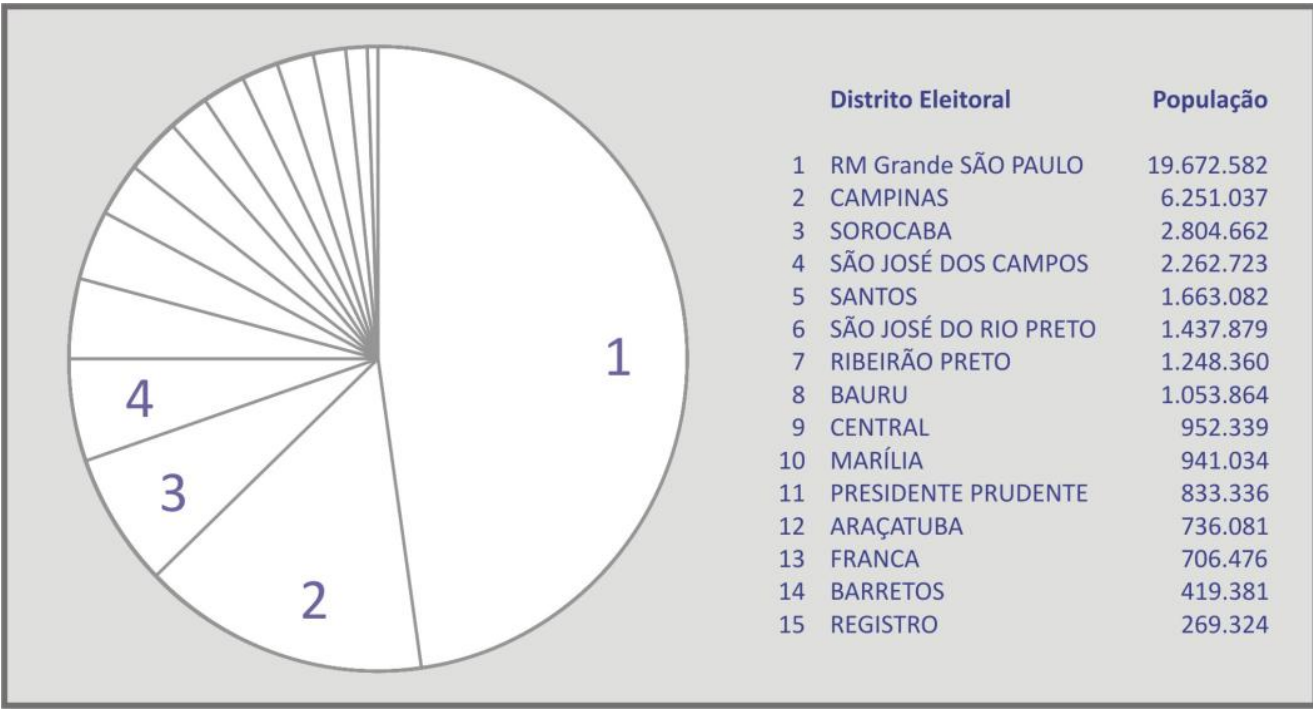

Fonte: Elaboração própria, com base em dados do IBGE.

Observou-se, todavia, que o desenho obtido compunha-se de unidades ainda bastante díspares, embora mais equânimes do que na primeira situação. Assim, aglutinaram-se as unidades de menor contingente populacional e dividiram-se algumas RAs. Foram mantidas as RAs de Sorocaba e São José dos Campos, fundindo-se Presidente Prudente a Marília, Araçatuba a Bauru, Central a São José do Rio Preto, Barretos e Franca a Ribeirão Preto e, no litoral, Registro a Santos, chegando-se a nove unidades. Com a divisão da RA Campinas em dois DEs (distritos eleitorais), tem. se, assim, dez unidades, das quais a menor totaliza 1,8 milhão (Marília) e a mediana 2,3 milhões de habitantes (Ribeirão Preto), mantendo-se a RMSP como a maior unidade, como apresentado na Figura 5: 
Figura 5

Distribuição da população nos distritos eleitorais

criados ap6s aglutinação e subdivisão de Regiões Administrativas (São Paulo)

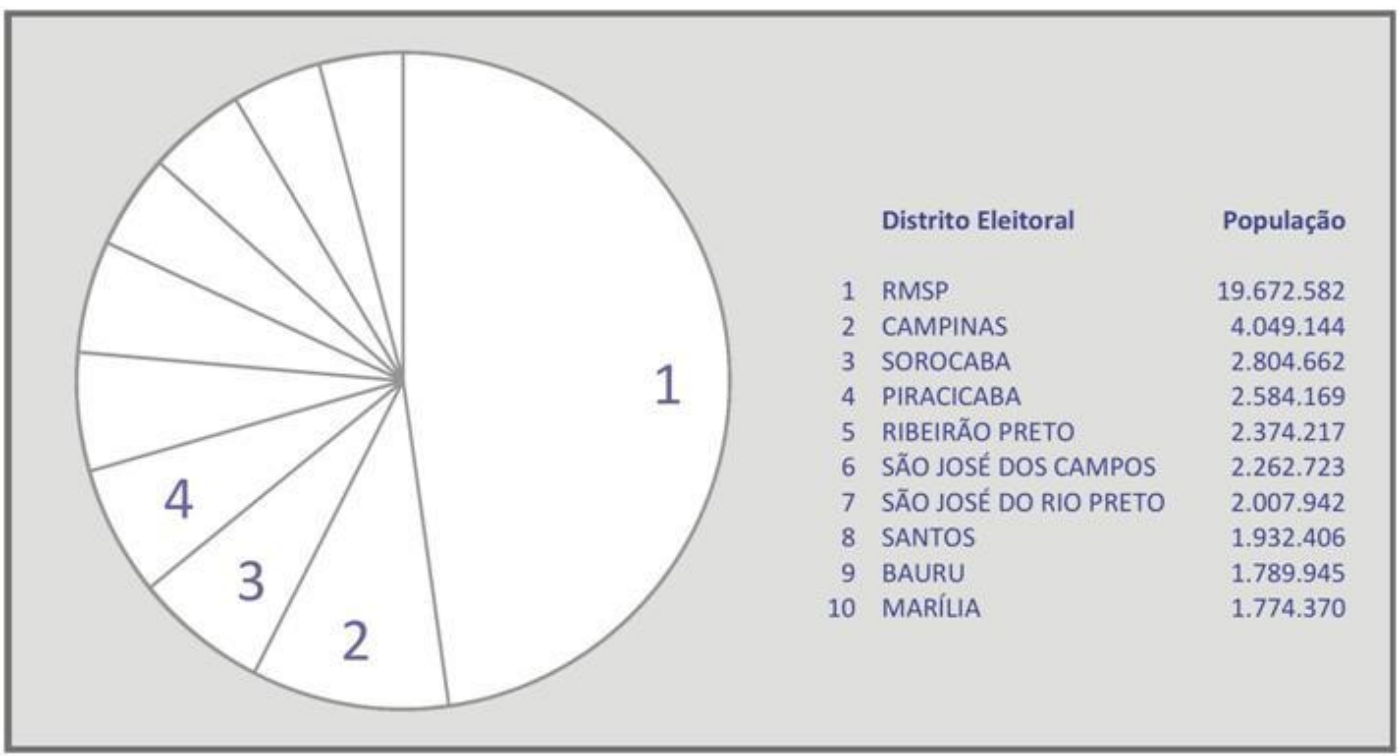

Fonte: Elaboração própria, com base em dados do IBGE.

Os últimos passos da elaboração cartográfica para a compartimentação do território paulista em DEs focaram na RMSP, aglutinando-se os municípios no entorno da capital e dividindo-se o município de São Paulo. Para o entorno da capital, chegou-se ao total de três DEs: Oeste (Osasco, de Francisco Morato a Juquitiba), Nordeste (Guarulhos/Mogi das Cruzes) e Sudeste (região do ABC).

Para o município de São Paulo, apresentaram-se dois recortes válidos para compartimentação, os distritos (96) e as subprefeituras (31). A opção recaiu sobre as segundas, por conta de eventual associação da logística eleitoral aos equipamentos de organização da gestão municipal. Dentro do possível, aglutinaram-se os territórios das subprefeituras conforme as tradicionais Zonas Cardeais, obtendo-se quatro distritos eleitorais: Norte (sete subprefeituras ao norte do rio Tietê - de Perus a Vila Maria), Leste (sete subprefeituras a leste do rio Aricanduva - de Penha a Cidade Tiradentes, mais São Mateus, num total de oito unidades), Sul (de Jabaquara a Campo Limpo e demais subprefeituras até o extremo do município, num total de sete unidades) e Central, composta pelos territórios das nove subprefeituras do arco sudoeste-sudeste (de Butantã a Aricanduva). Dessa forma, da compartimentação do território da RMSP resultaram sete distritos eleitorais, como se demonstra na Figura 6: 
Figura 6

RMSP com municípios agrupados e o município de São Paulo subdividido em distritos eleitorais

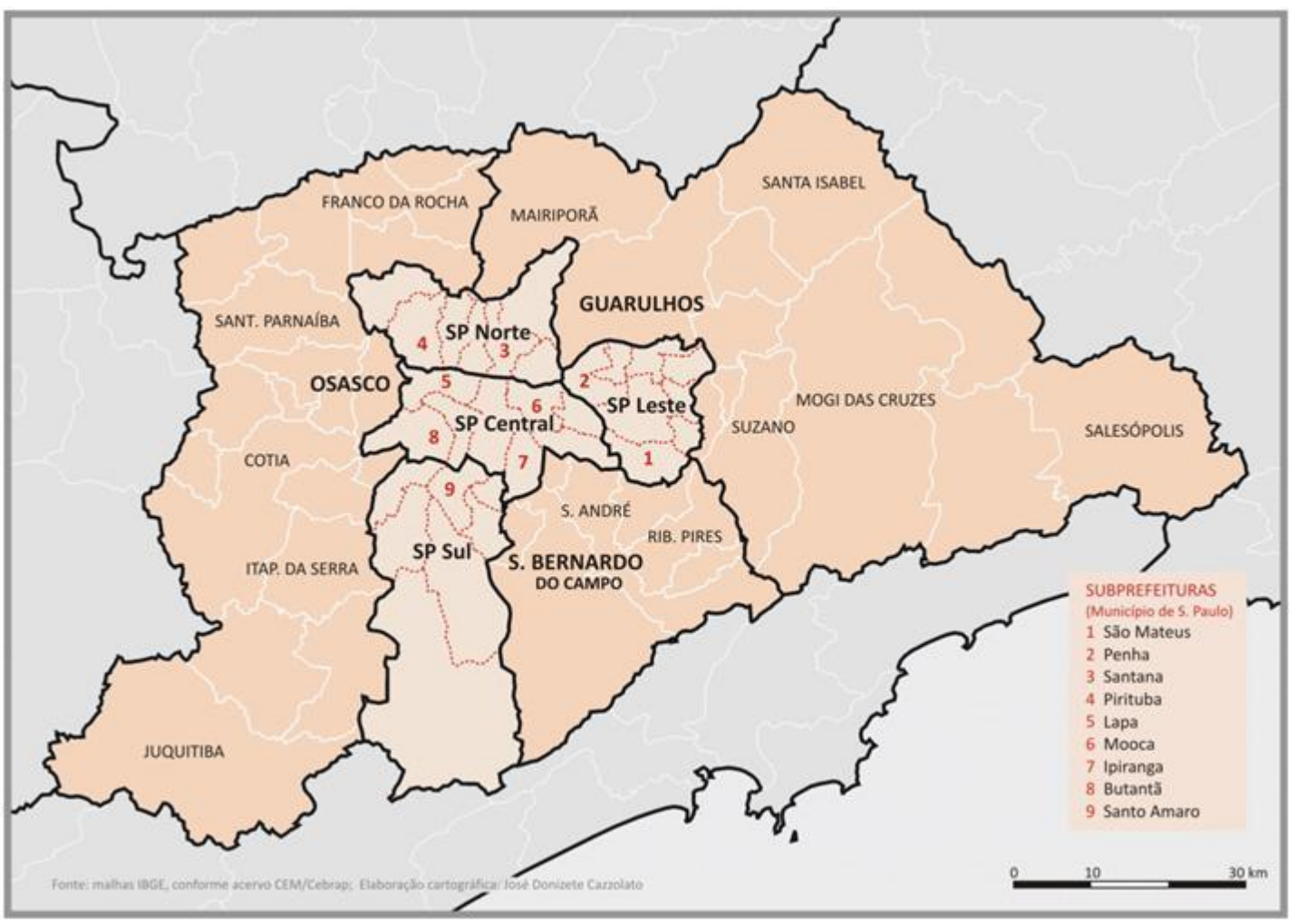

Fonte: Elaboração própria, com base em dados do IBGE.

Finalizada a definição dos DEs na RMSP, chegou-se ao desenho final do ensaio regional proposto, num total de 16 unidades territoriais. Seus extremos demográficos são 1,8 milhão (DE de Marília) e 4,0 milhões (DE de Campinas), posicionando-se a mediana em 2,55 milhões (Piracicaba/São Bernardo do Campo), como se pode conferir na Figura 7. Percebe-se o equilíbrio demográfico obtido, conforme exibido na Figura 8, apesar das significativas diferenças no tocante à extensão territorial das unidades: 
Figura 7

Estado de São Paulo dividido em novos distritos eleitorais

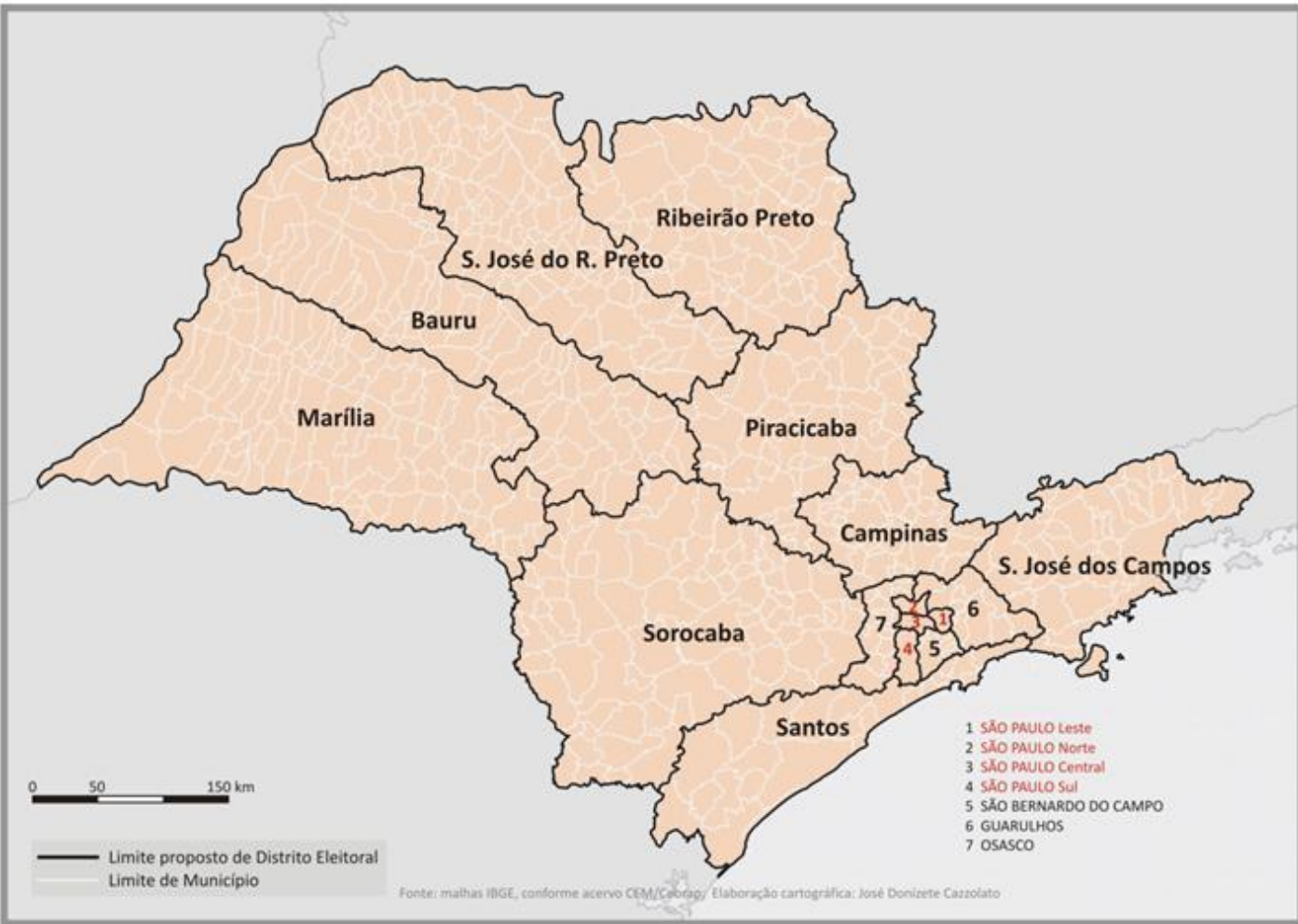

Fonte: Elaboração própria, com base em dados do IBGE. 
Figura 8

Distribuição da população de São Paulo nos novos distritos eleitorais

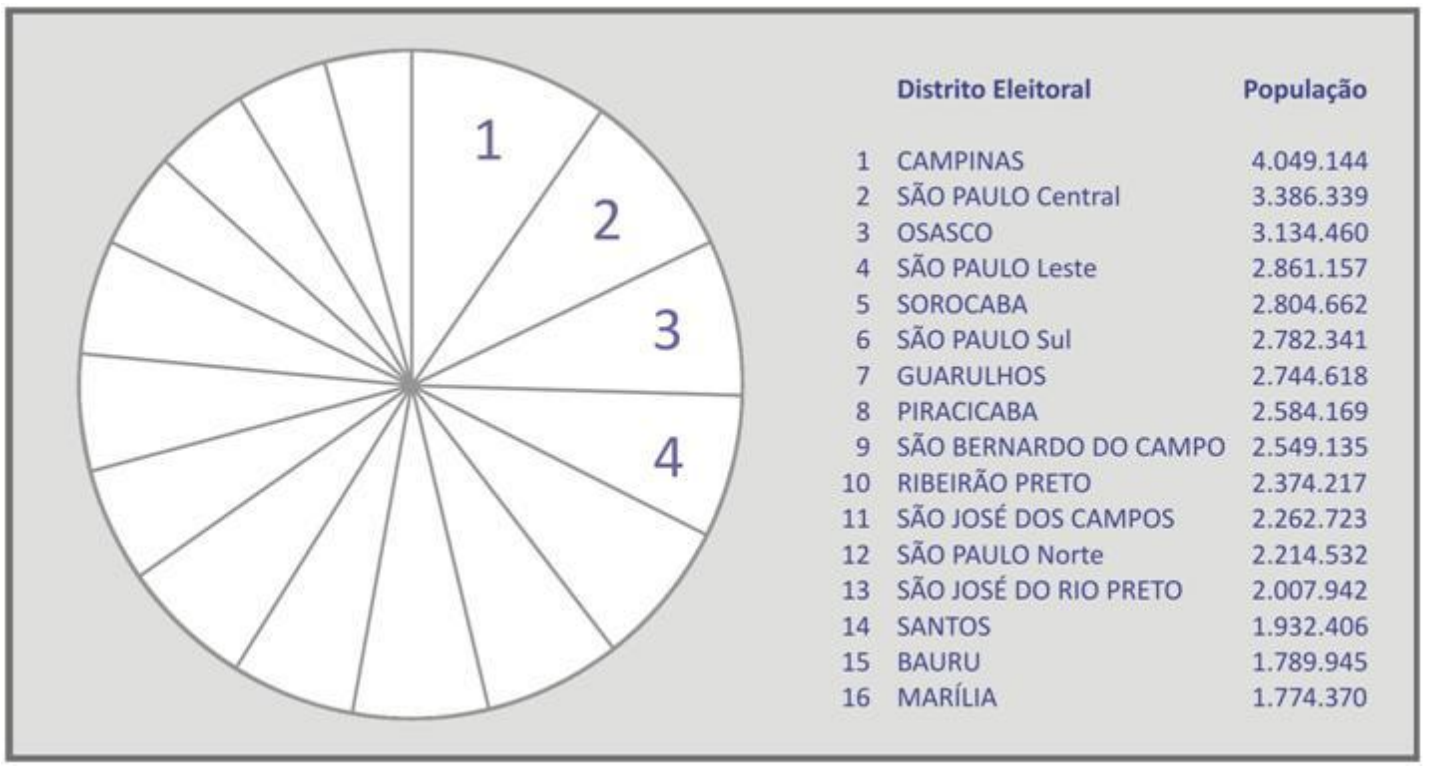

Fonte: Elaboração própria, com base em dados do IBGE.

Distritos eleitorais no estado de Pernambuco: um ensaio de distritalização

A bancada pernambucana totaliza 25 representantes na Câmara Federal, numa proporção ideal de 352 mil habitantes para cada deputado. Com território de dimensões 2,5 vezes menor que o paulista, Pernambuco também concentra mais de $40 \%$ de sua população em sua maior RM, a do Recife.

Do mesmo modo que no caso de São Paulo, a divisão aqui proposta leva em consideração os diversos fatores e elementos da organização do espaço, como distribuição e dimensão dos centros urbanos, rede viária, processos de ocupação, identidades historicamente construídas etc., sem perder de vista a contiguidade territorial e o possível equilíbrio entre as partes. Diferentemente de São Paulo, porém, para Pernambuco levamos em conta a geomorfologia e os grandes ecossistemas a ela associados, que se impõem na organização da economia e da cultura nordestinas. Conforme já destacado, buscou-se aqui que os recortes tivessem consistência geográfica. Seguem os passos utilizados na elaboração da divisão do estado em seis distritos eleitorais.

\section{Regionalização pernambucana}

A tradição acadêmica e a percepção popular do Nordeste oriental (do Rio Grande do Norte à Bahia) são unânimes na compartimentação do espaço em Zona da Mata (a porção litorânea), Agreste (faixa intermediária) e Sertão (a porção mais interiorana). A prática do Instituto Brasileiro de Geografia e Estatística (IBGE) na divisão das micro e mesorregiões geográficas consagrou essa terminologia, como demonstrado na Figura 9: 
Figura 9

Estado de Pernambuco dividido em micro e mesorregiões do IBGE

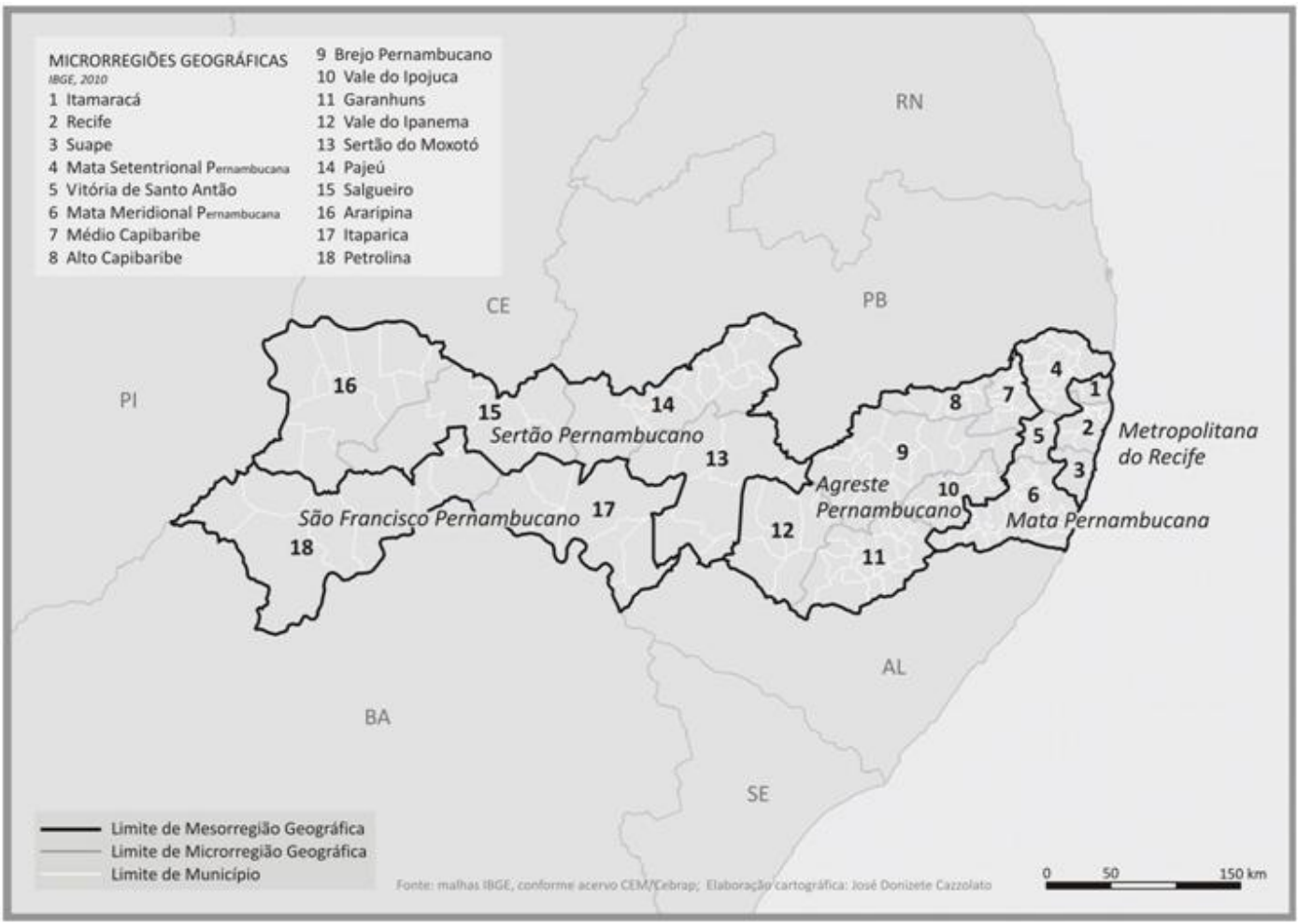

Fonte: Elaboração própria, com base em dados do IBGE.

Estudos mais recentes da organização geoeconômica nordestina, porém, apontam a importância dos centros urbanos que se reforçaram nas últimas décadas, condição que levou, em muitos locais, à ruptura dos arranjos regionais tradicionais. Exemplos são os projetos Regiões de Influência das Cidades, cuja última edição é de 2007, e Divisão Urbano-Regional, de 2013, ambos publicados pela Coordenação de Geografia do IBGE.

O agrupamento de alguns municípios formando RMs também é uma prática relativamente nova. A RM do Recife, instituída em 1973, tem sido bastante utilizada nos estudos de geografia, sociologia, economia etc., assim como no planejamento das ações de governo. Reúne 14 municípios, totalizando 3,7 milhões de habitantes.

Em 2001, uma segunda RM foi instituída no estado, mas com terminologia distinta: por agrupar também unidades municipais do estado da Bahia, foi denominada Região Administrativa Integrada de Desenvolvimento do Polo Petrolina/PE e Juazeiro/BA, com sede em Petrolina. Contudo, nenhuma das duas RMs foi utilizada diretamente neste estudo, como se detalha a seguir. 


\section{Distritos eleitorais}

Por questões demográficas e pelo critério de equilíbrio entre os DEs, decidiu-se por utilizar, como DE, apenas a porção mais central e de conurbação mais densa da RM do Recife, nominalmente, os municípios de Recife, Olinda, Paulista e Camaragibe. Os demais municípios somaram-se aos extrametropolitanos na composição dos outros dois DEs litorâneos: Mata Sul e Mata Norte, como se pode conferir na Figura 10:

Figura 10

Região Metropolitana do Recife e entorno

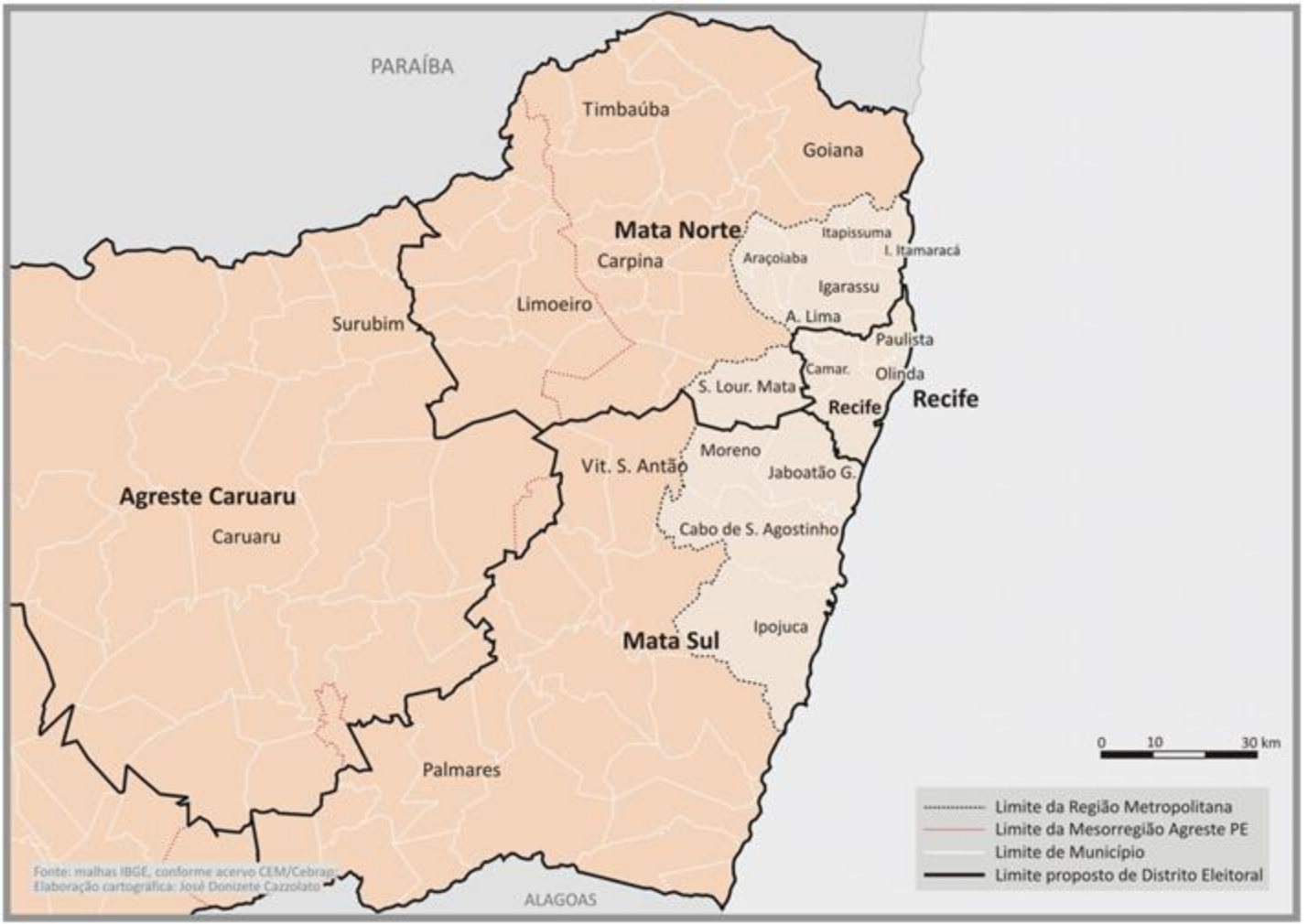

Fonte: Elaboração própria, com base em dados do IBGE.

Observe-se que o DE de Mata Norte incluiu a microrregião Médio Capibaribe (Limoeiro), que faz parte dos domínios do Agreste. No entanto, faz parte da área intermediária de influência do Recife, conforme o citado estudo do IBGE de 2013, ou seja, mantém fortes laços com o território ao qual foi inserida.

Acertadas as unidades territoriais para a porção mais densa do estado, passamos ao Agreste e ao Sertão, regiões de baixa densidade populacional e de importantes contingentes rurais. Os polos principais do interior pernambucano são Caruaru, Garanhuns e Petrolina, e, em segundo nível, Arcoverde, Afogados da Ingazeira, Serra Talhada e Araripina. A localização desses polos (Figura 11) consolidou o contorno dos distritos eleitorais aqui propostos: 
Figura 11

Estado de Pernambuco e grandes polos do interior

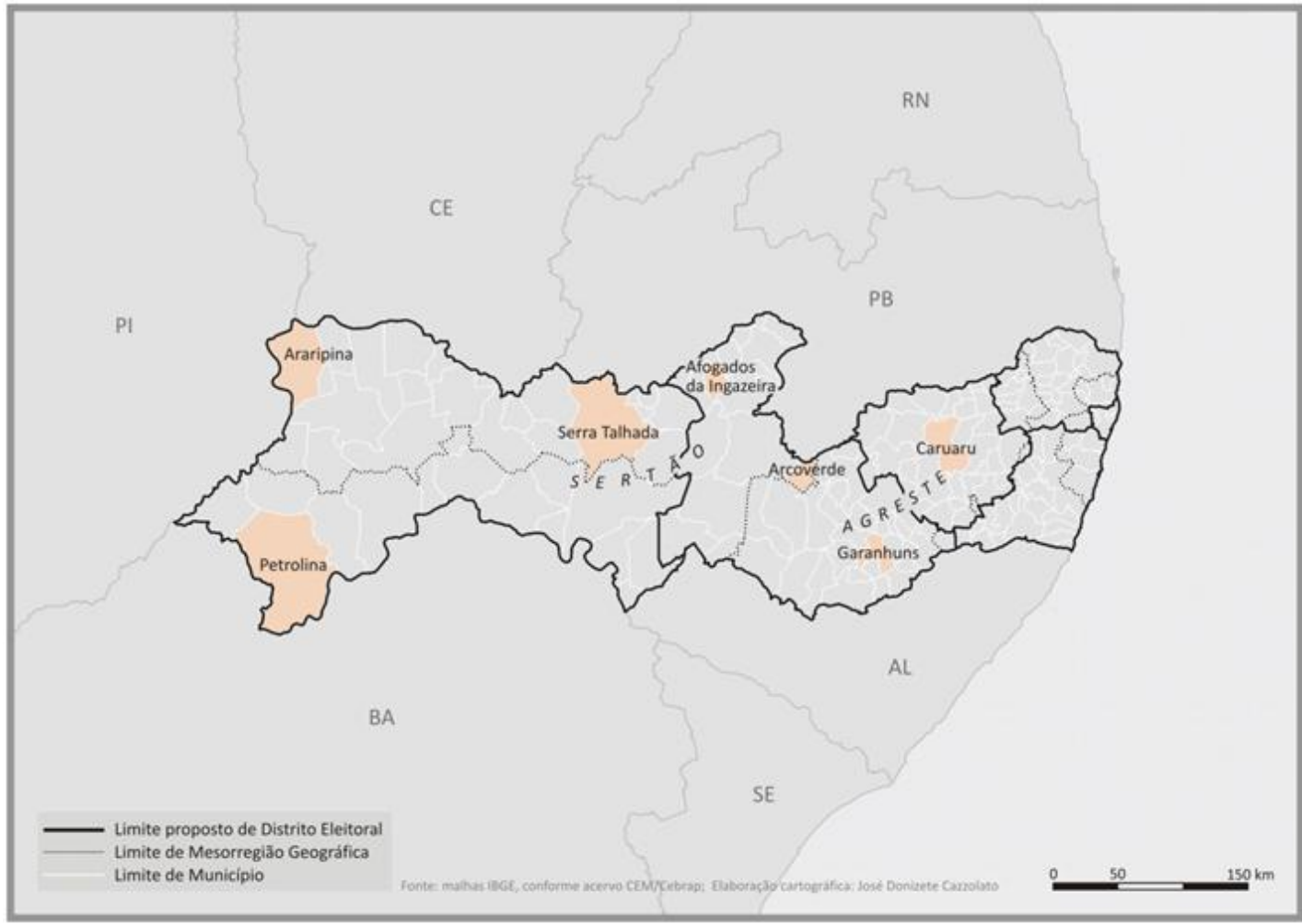

Fonte: Elaboração própria, com base em dados do IBGE.

Caruaru e Garanhuns são centros urbanos do Agreste, Arcoverde fica na interface com o Sertão e os demais são sertanejos. Na distritalização eleitoral proposta, Caruaru e seu entorno agrestino compõem um DE, Garanhuns se junta a Arcoverde e Afogados da Ingazeira, e os demais - Serra Talhada, Araripina e Petrolina - formam o sexto distrito eleitoral pernambucano. Dessa forma, obtivemos três DEs interioranos e três metropolitanos (ou macrometropolitanos), como representado na Figura 12. Os valores demográficos dos DEs pernambucanos estão ordenados na Figura 13, que expõe o equilíbrio entre as unidades: 
Figura 12

Estado de Pernambuco dividido em novos distritos eleitorais

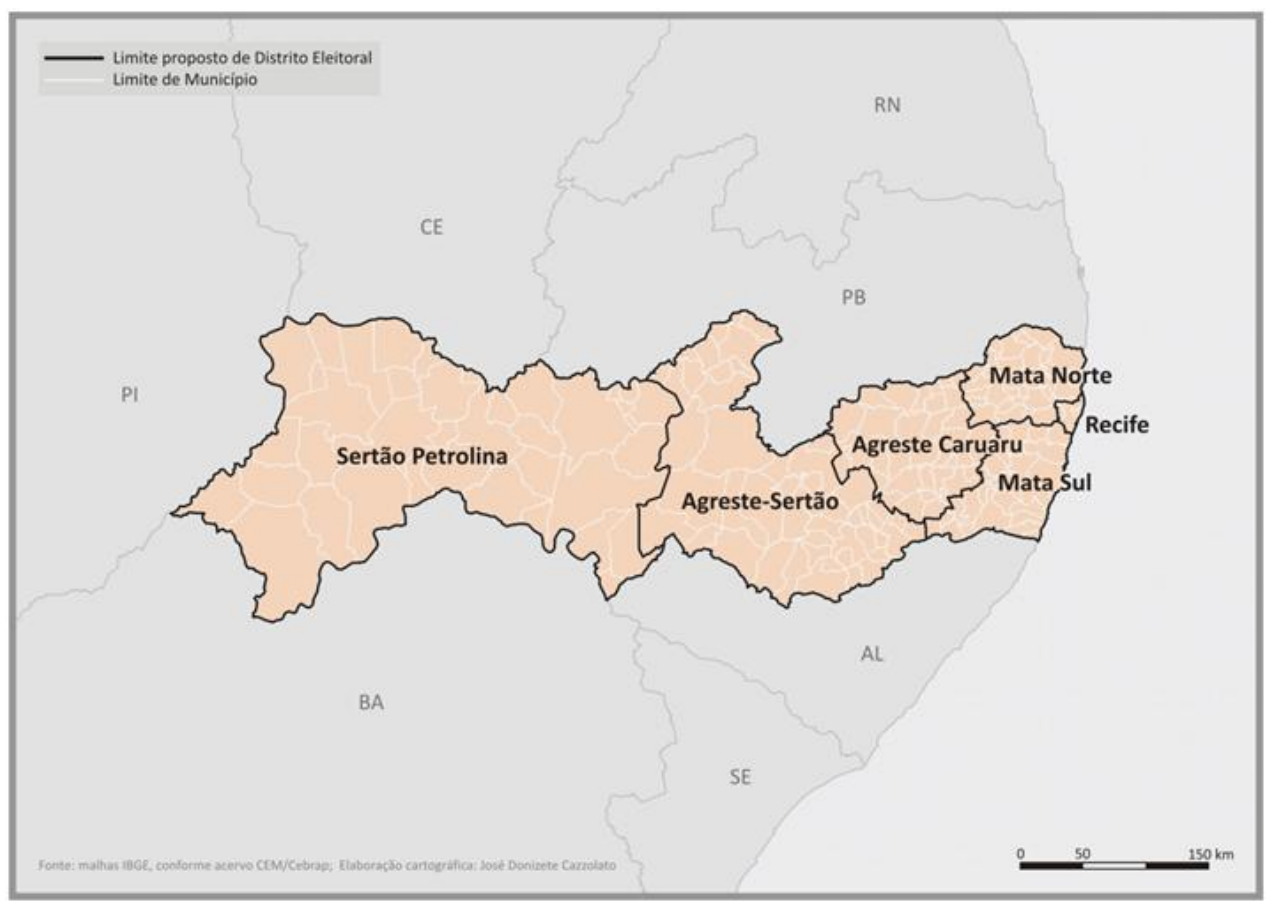

Fonte: Elaboração própria, com base em dados do IBGE.

Figura 13

Distribuição da população de Pernambucano em novos distritos eleitorais

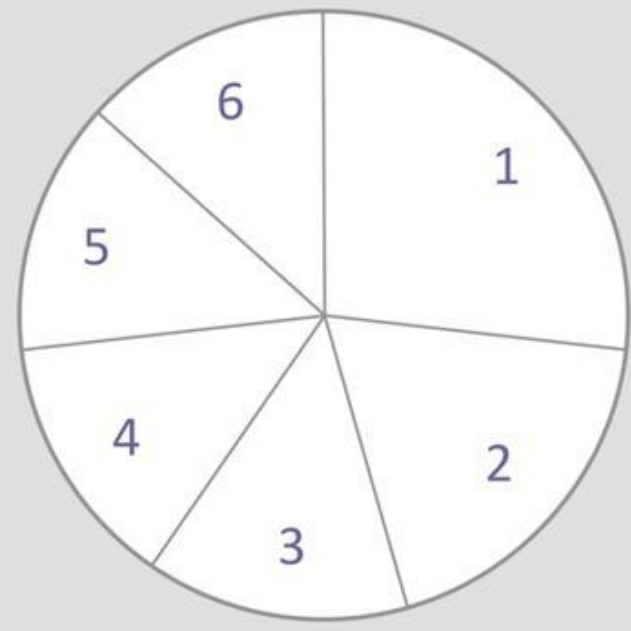

Distrito Eleitoral

População

1 RECIFE

2.363.045

2 MATA SUL

1.644 .749

3 AGRESTE CARUARU $\quad 1.230 .196$

4 SERTÃO PETROLINA $\quad 1.193 .700$

5 AGRESTE SERTÃO 1.188 .420

6 MATA NORTE 1.176 .338

Fonte: Elaboração própria, com base em dados do IBGE. 
Comparando-se com a divisão proposta para o estado de São Paulo, observa-se que os resultados são similares. Entre os DEs paulistas, o menos populoso equivale à metade do segundo colocado, e em Pernambuco essa relação se dá entre os dois extremos, com a particularidade de os quatro menores terem praticamente a mesma população. No tocante à extensão territorial das unidades, resultaram grandes diferenças no estado de São Paulo, por conta da extrema concentração demográfica da RMSP. Em Pernambuco, essa situação ocorreu apenas com o DE de Recife, cuja extensão equivale aos DEs originários da divisão do município de São Paulo.

Patrick Silva · patricksilva27@gmail.com

Andreza Davidian · davidian.andreza@gmail.com

Andréa Freitas - amfreitas1@gmail.com

José Donizete Cazzolato ·donizete@cebrap.org.br

Submetido à publicação em junho de 2013.

Versão final aprovada em agosto de 2014. 